Adaho chapter
Established 1963

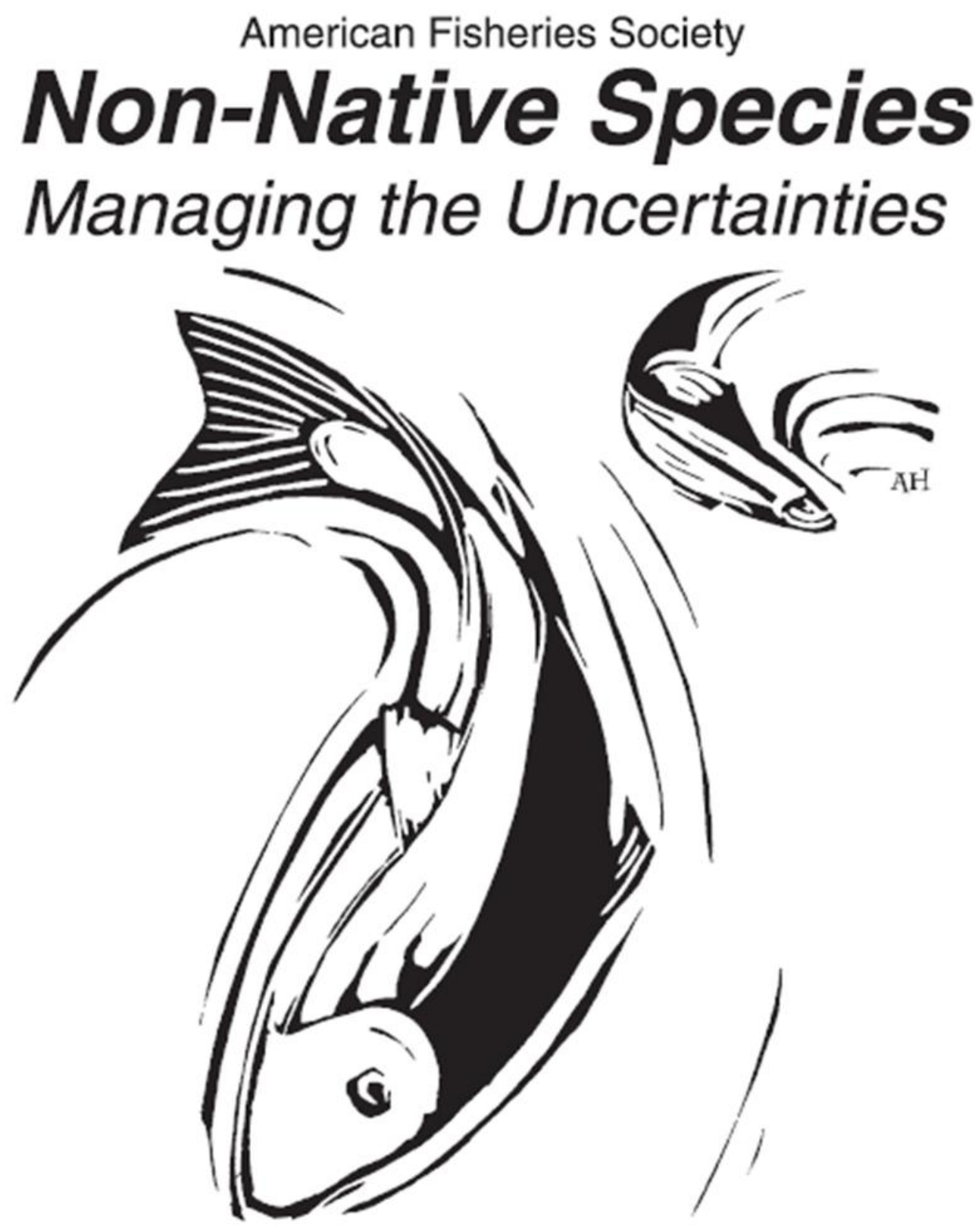

2012 Annual Meeting Coeur d' Alene, Idaho

Coeur d'Alene Resort

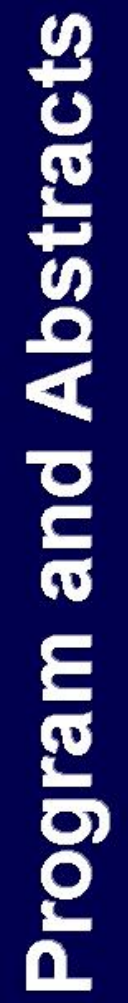

March 7-9, 2012 


\section{Thanks to our Meeting Sponsors!}
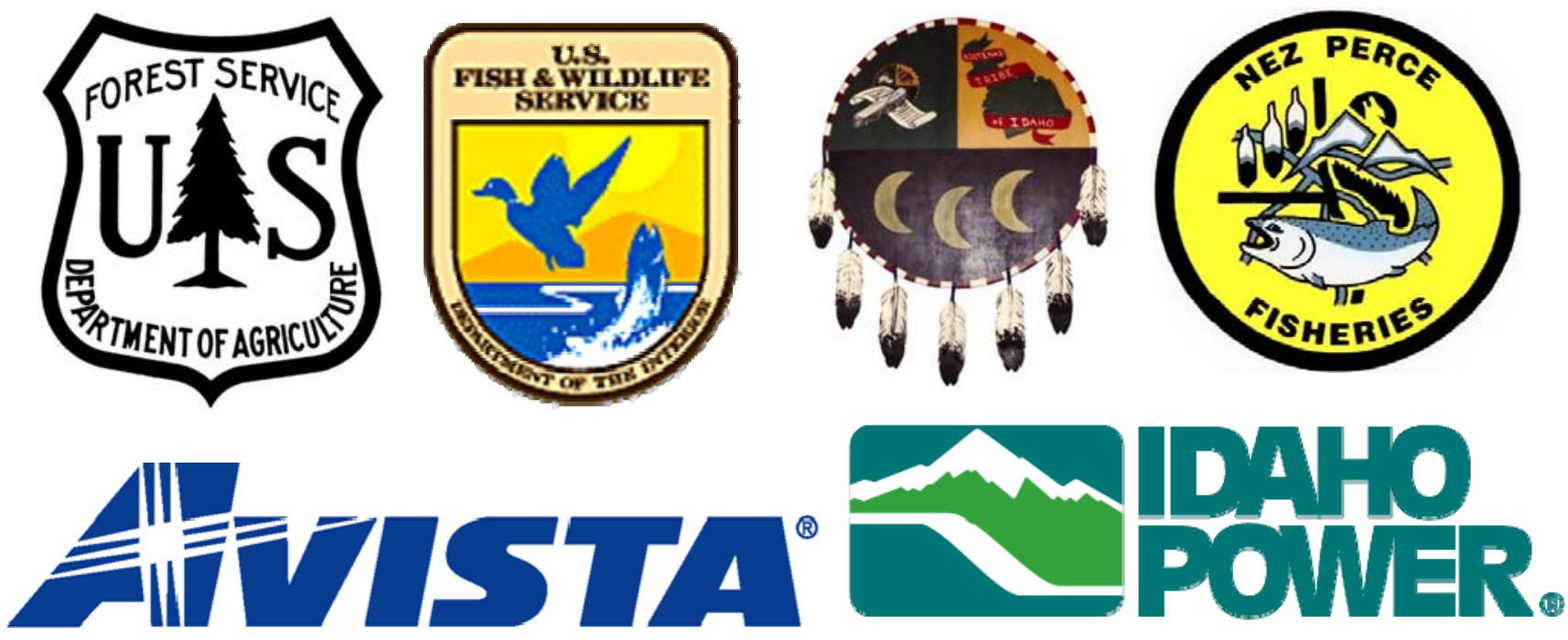

An IDACORP Company
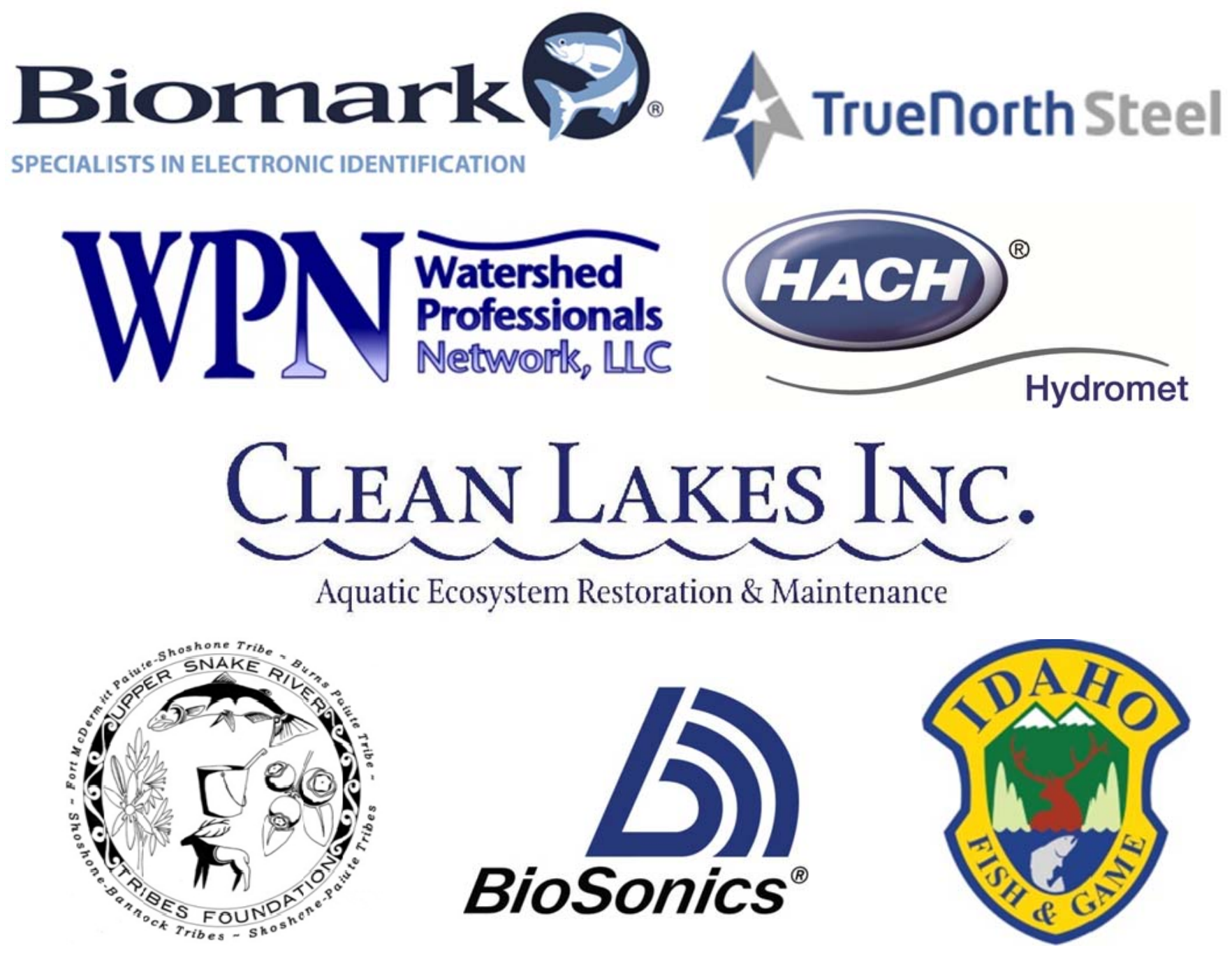


\section{ICAFS EXCOM AND COMMITTEE CHAIRS}

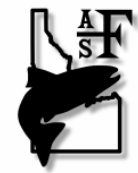

\section{Executive Committee}

Jason Vogel, President

Dmitri Vidergar, President Elect

Joe DuPont, Vice President

Ernest Keeley, Past President

Bill Horton, Secretary

Tim Copeland, Treasurer

Mary Faurot, Nominations Chair

Samuel Bourret, Palouse Unit Pres.

Matt Green, Portneuf Unit President

\section{Committee Chairs}

Mike Edmondson, Anadromous Fish

Lars Alsager, Aquaculture

Patrick Kennedy, Fundraising

Chris Sullivan, Fundraising

Dona Horan, Membership

Steve Elle, Mentoring

Cathy Gidley, Native Fish

Corie Laude, Native Fish

Lauri Monnot, Public Education

Corey Lyman, Fish Habitat

Stephanie Hallock, Fish Habitat

Dan Scaife, Fish Habitat
(208) 843-7145 jasonv@nezperce.org

(208) 383-2216 dvidergar@usbr.gov

(208) 799-5010 joe.dupont@idfg.idaho.gov

(208) 282-3145 keeleme@isu.edu

(208) 344-7358 brthorton@msn.com

(208) 465-8404 tim.copeland@idfg.idaho.gov

(208) 373-4309 mfaurot@fs.fed.us

(860) 508-3565 bour6715@vandals.uidaho.edu

(208) 251-0197 greenmat3@isu.edu

(208) 331-1551 mike.edmonson@osc.idaho.gov

(208) 536-2283 lars.alsager@idfg.idaho.gov

(208) 465-8404 pat.kennedy@idfg.idaho.gov

(208) 465-8404 chris.sullivan@idfg.idaho.gov

(208) 373-4399 dhoran@fs.fed.us

(208) 465-8404 steve.elle@idfg.idaho.gov

(208) 610-6139 cathy.gidley@idfg.idaho.gov

(208) 255-8567 corie.laude@idfg.idaho.gov

(208) 373-0461 lauri.monnot@deq.idaho.gov

(208) 557-5838 clyman@fs.fed.us

(208)686-0701 shallock@cdatribe-nsn.gov

(208) 767-7488 dscaife@fs.fed.us

\section{Committee Room Assignments}

\begin{tabular}{ll}
\hline Committee & Room \\
\hline Anadromous Fish & Bay 1A \\
Fish Culture & Bay 5 \\
Mentoring & lobby \\
Native Fishes & Bay 6 \\
Public Education & lobby \\
Riparian & Bay 5 \\
Fish Habitat & Bay 1B \\
\hline
\end{tabular}




\section{Floor Plan for Coeur d'Alene Resort}

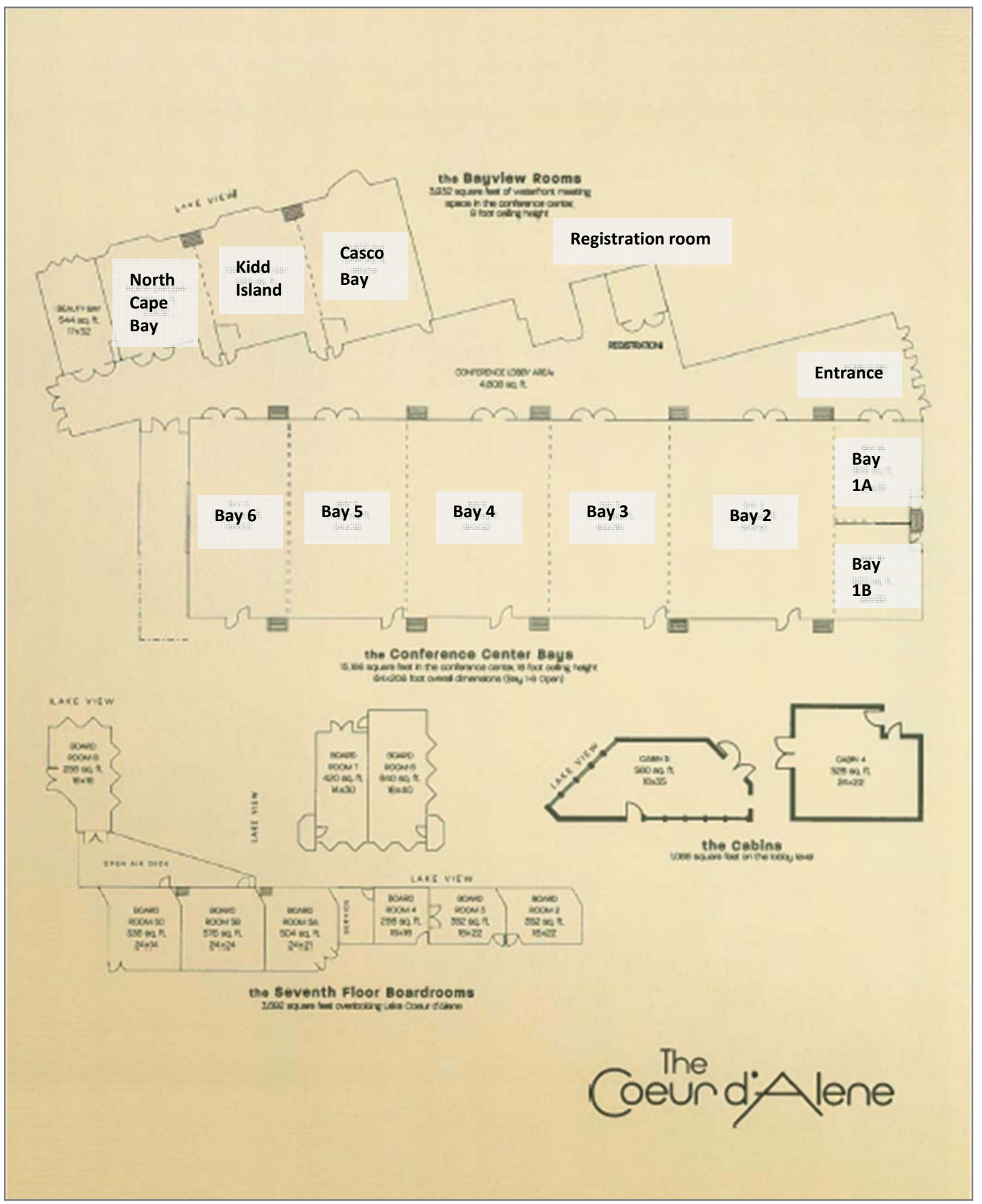


Wednesday, March 7

8:00-8:20 AM Opening Remarks and Presidential Message

ICAFS President, Jason Vogel

Plenary Session: Non-Native Species - Managing the Uncertainties

Location: Bay 5/6

8:20-8:30 Introduction to Plenary Session

Dmitri Vidergar, President-Elect

Jeff Heindel, Moderator

8:30-9:00 The surprising history of 'biological invasions'

Matt Chew, Arizona State University

9:00-9:30 Greeting the elephant in the room: our complex relationship with nonnative sport fishes Beth Sanderson, NOAA Fisheries

9:30-10:00 Nonlinear interactions between native and nonnative fishes: implications for management and conservation Michael Quist, University of Idaho

10:00-10:20 Break (Casco Bay/Kidd Island)

10:20-10:50 Invasive Aquatic Plant Treatment and Prevention in Idaho

Thomas Wolff, Idaho State Department of Agriculture

10:50-11:20 Emerging Lessons: Unforeseen Consequences of Invasive Species for Stream-Riparian Food Webs and Ecosystem Processes

Colden Baxter, Idaho State University

11:20-11:50 Panel Discussion

All Speakers

11:50-11:55 Concluding Remarks

Dmitri Vidergar

11:55-1:25PM Box Lunch: Committee Breakouts (Room assignments - Table on page 1)

Session 1: Related Topics to Plenary

Location: Bay 5/6

1:25-1:25 PM Introduction to Session

Matt Davis, Moderator

1:25-1:45 WHERE'S THE BEEF? Why 20 Years of Predicted Global Warming Effects on Fish

Distributions Remain Unsubstantiated

Daniel J. Isaak, U.S. Forest Service, Rocky Mountain Research Station, Boise Aquatic

Sciences Laboratory

1:45-2:05 Declining Native Fish Composition in the Middle Snake River and the Importance of Spring Habitats

James Chandler, Idaho Power Company

2:05-2:25 How Big is Lake Lowell's Common Carp Problem?

Joe Kozfkay, Idaho Department of Fish and Game 
Christopher D. Smith, University of Idaho

2:45-3:05 Evaluating and Addressing Impacts of Non-Native Fish Species Across Life-Stages of Adfluvial Westslope Cutthroat Trout in the Coeur d'Alene Basin Jon Firehammer, Coeur d'Alene Tribe

Estimating Rates of Pelican Predation on Yellowstone Cutthroat Trout in the Upper Blackfoot River System Matt T. Green, Idaho State University

Break (Casco Bay/Kidd Island)

Pend Oreille River Fisheries Management: The Past, Pike, and Future Jason M. Connor, Kalispel Tribe of Indians

Studies on Largemouth Bass (Micropterus salmoides) Designated as Top Nuisance Fish in Republic of Korea Jinwon Seo, University of Idaho

Thermal Acclimation and Adaptation in Redband Trout from Desert and Montane Populations

Shawn R. Narum, Columbia River Inter-Tribal Fish Commission

4:50-5:10 Climate Change Effects on Stream and River Temperatures Across the Northwest U.S. from 1980-2009

Daniel J. Isaak, U.S. Forest Service, Rocky Mountain Research Station, Boise Aquatic Sciences Laboratory

\section{5:10-5:15 Concluding comments and wrap-up}

5:30-6:15 MENTORING SOCIAL: Eagles Lodge, 209 E. Sherman Avenue - See map below.

6:30- ??:?? STUDENT MIXER: Eagles Lodge, 209 E. Sherman Avenue - See map below.

8:30-11:00 AFS Fish Jam Practice: Location: Bay 2

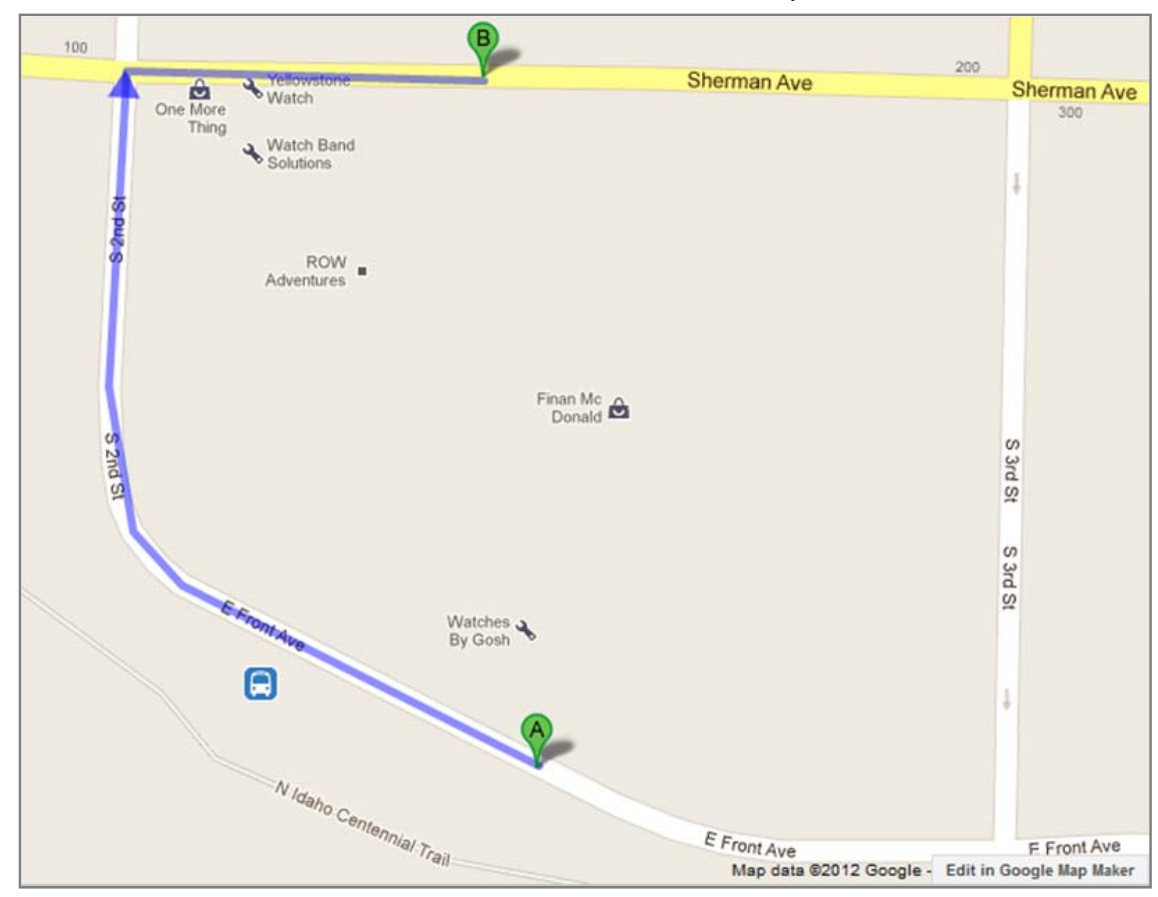

Resort: Dot A

Eagles Lodge: Dot B - Location of Mentoring Social \& Student Mixer Five minute walk from the Resort. 


\section{Thursday, March 8 (Concurrent Sessions)}

\section{6:00-7:00 AM ICAFS Spawning Run - Location: Meet at Registration Desk Sponsored by Biomarls}

8:00-8:10 Announcement and introduction to Session

8:10-8:30 A Critical Assessment of the Ecological Assumptions Underpinning Compensatory Mitigation of Salmon Derived Nutrients Scott F. Collins, Idaho State University 8:30-8:50 Nutrient Flux by Chinook Salmon in Idaho Streams: The Ins and Outs, and Implications for Management

Andre E. Kohler, Shoshone-Bannock Tribes

8:50-9:10

9:10-9:30

9:30-9:50

9:50-10:15

$10: 15-10: 35$

10:35-10:55
Supportive Breeding Boosts Natural Population Abundance Without Inflicting Negative Fitness Impacts on Wild Chinook Salmon in Johnson Creek, Idaho Maureen A. Hess, Columbia River InterTribal Fish Commission

Comparisons of Adult Demographics for a Supplemented Summer Chinook Population: A Companion to Parentage Assignment Craig D. Rabe, Nez Perce Tribe DFRM Thermal Shift in Maximum Consumption Helps Explain Bioenergetics and Growth by Subyearling Fall Chinook salmon John M. Plumb, University of Idaho

Break (Casco Bay/Kidd Island)

Session 3-A: Chinook Salmon Ecology and Management

Moderator: Eric Crawford

Location: Bay 5

Seasonal Growth Rates, Smolting and Early Male Maturation in Hatchery Chinook Salmon Programs in the Columbia River Basin

Brian Beckman, NOAA Fisheries

Characterizing Juvenile Chinook Salmon Life History Variability in the Willamette Valley Using Otoliths and Scales Samuel Bourret, University of Idaho
Session 2-B: Native Fish Ecology and Habitat Moderator: Dan Scaife

Location: Bay 6

Announcement and introduction to Session Evaluation of Artificial Markers for Monitoring Releases of Burbot (Lota lota) in the Kootenai River

Neil Ashton, University of Idaho

Deep Water Spawning Observations and Effective Incubation Habitat Modeling for Redband Trout, Spokane River, WA

Tim Vore, Avista Corporation

A Long-Term Comparison of Yellowstone

Cutthroat Trout Abundance in Idaho

Steven Elle, Idaho Department of Fish and Game

Update on the Status of Pygmy Whitefish in Idaho

Melo A. Maiolie, Idaho Department of Fish and Game

How Do Stream Food Webs Respond to the Addition of Salmon Carcass Analogs in Idaho Streams?

David P. Richardson, Shoshone-Bannock Tribes

Break (Casco Bay/Kidd Island)

Session 3-B: Native Fish Ecology and Management

Moderator: Trevor Watson

Location: Bay 6

Influence of Barriers to Movement on the Population Genetic Structure of Westslope Cutthroat Trout Sammy L. Matsaw Jr., Idaho State University

Distribution and Genetic Structure of a Needle in the Fragmented Haystack: The Tale of a Rare High-Desert Minnow, the Northern Leatherside Chub

$$
\text { Jason Blakney, Idaho State University }
$$


10:55-11:15

11:15-11:35

$11: 35-11: 55$

$11: 55-2: 10$

2:10-2:15

2:15-2:35

2:35-2:55

2:55-3:15

3:15-3:35
Trends in Length at Age and Age at Maturity of Two Stocks of Hatchery Chinook Salmon and Adjacent Natural Populations in Idaho John Cassinelli, Idaho Department of Fish and Game

A Life Cycle Modeling Approach to Life History Evolution in a Spatially Structured Population of Fall Chinook Salmon Jens Hegg, University of Idaho

Effect of Creel Survey Design and Catch Rate Estimation on Total Catch Estimates in Chinook Salmon Fisheries in Idaho Joshua L. McCormick, University of Idaho

Business Luncheon (Bay 2/3)

Session 4-A: Steelhead Ecology and Management

Moderator: Lars Alsager

Location: Bay 5

Introduction to Session

Comparison of Juvenile Life History Strategies Exhibited by Steelhead within the Potlatch River Drainage, Idaho

Brett J. Bowersox, Idaho Department of Fish and Game

The Origin and Distribution of Kelt Steelhead Trout in the Snake River, ID: Genetic Stock ID at Lower Granite Dam

Andrew Matala, Columbia River InterTribal Fish Commission

Origin of Hatchery Steelhead Kelts Determined by Parentage-based Tagging (PBT)

Craig A. Steele, Pacific States Marine Fisheries Commission (PSMFC)/Idaho Department of Fish and Game Effects of Body Mass, Water Temperature, and Consumption Rates on Juvenile Steelhead (Oncorhynchus mykiss) Growth in a Hydrologically Altered Watershed Knut Marius Myrvold, University of Idaho
Effects of Wildfire and Debris Flows on Downstream Insect Fluxes and Consequences for Drift - Feeding Fish in Recipient Confluence Habitats

Hannah E. Harris, Idaho State University

Prioritizing Restoration Activities in Two

Watersheds of the Coeur d'Alene Subbasin to Improve Habitat for Westslope Cutthroat Trout Stephanie Hallock, Coeur d'Alene Tribe Fisheries Program

A Watershed Scale Test of Optimal Foraging in a Variable Environment

Brian Kennedy, University of Idaho

Business Luncheon (Bay 2/3)

Session 4-B: Management, Education, and Methods Application

Moderator: Stuart Rosenberger

Location: Bay 6

Introduction to Session

Lifecycle Assessment Integrating Two or More Species to Improve Sustainability in Marine Aquaculture

Lubia Cajas Cano, University of Idaho

Effects of Initial Feed Timing on Triploid

Rainbow Trout Fry at Grace Fish Hatchery Beau J. Gunter, Idaho Department of Fish and Game

Hydrologic Regime Influence on Age-1 Walleye Recruitment in Lake Roosevelt, Columbia River Benjamin K. Cross, Washington State University

Seven Years of Nutrient Addition to Restore Fisheries in the Kootenai River, Idaho Cathy Gidley, Idaho Department of Fish and Game 
3:35-3:55

$4: 35-4: 55$
A Comparison of the Nutritional and Energetic Status of Kelts From the Snake River and Coastal Situk River, AK Using Blood Plasma Metrics

Zachary L. Penney, University of Idaho Migration and Physiology of Clearwater River Steelhead Kelts Bryan Jones, University of Idaho

The Role of rpoB Mutation in Rifampicin Attenuation of Flavobacterium psychrophilum Karol Gliniewicz, Washington State University

Using Multiple Sonar Deployments to Improve Run-Size Estimates of Anadromous Fishes Jacob B. Hughes, North Carolina State University
Databasing Data to Improve Understanding of Fish Ecology and Management Uncertainties Alexander K. Fremier, University of Idaho

Suppression of Cannibalism During Larviculture of Burbot (Lota lota maculosa) Through Size Grading Josh Egan, University of Idaho Species-Wide Genetic Analysis of Westslope Cutthroat Trout Daniel M. Bingham, Rocky Mountain Research Station

Resolving Cottid Confusion: Phylogeography of Sculpins in the Upper Columbia and Missouri River Basins

Michael K. Young, Rocky Mountain Research Station

\section{5:15-6:15 Poster Session Location: Casco Bay/Kidd Island}

Effects of Winter Ice Dynamics on Periphyton and Seston in a Central Idaho River Ecosystem Ryan Blackadar, Idaho State University

The Snake River Sockeye Captive Broodstock Program: A Review of the First Twenty Years and What's Migrating Upstream in the Future Travis Brown, Idaho Department of Fish and Game

Analysis of Survival and Downstream Migration Characteristics of Steelhead Kelts Using Instream PIT-Tag Arrays in the Potlatch River Drainage, ID Nicolas Davids, Pacific States Marine Fisheries Commission

Suitability of Habitat and Water Quality in the Meadow Reach of Boulder Creek for Rainbow Trout Deirdre Bingaman, Donnelly Elementary School $5^{\text {th }}$ Grade and McCall Outdoor Science School

Marine Mammal Predation in the Lower Columbia River Douglas Hatch, Columbia River Inter-Tribal Fish Commission

Evaluating Tiger Muskellunge to Remove Brook Trout from Idaho Alpine Lakes Eric Herrera, Idaho Department of Fish and Game

Genetic Estimation of Stock Abundance and Run-timing of Interior Columbia River Steelhead Passing Bonneville Dam Jon E. Hess, Columbia River Inter-Tribal Fish Commission

Prevalence of Otolith Aberrancy in Hatchery-Reared Juvenile Steelhead Trout from the Snake River Basin Heath Hewett, University of Idaho

Assimilation Efficiency of Utah Sucker and Speckled Dace Feeding on Chironomidae Larvae at Different Temperatures Nichelle Heyrend, Idaho State University

Genetic Analysis of Redband Trout in the Malad River, ID Tabitha Holden, Cascade Jr./Sr. High School 
A Large-Scale Field Assessment Using Underwater Epoxy to Permanently Install Sensors for Full Year Temperature Monitoring in Mountain Streams

Dona L. Horan, Sherry Wollrab, Daniel J. Isaak, and Brett B. Roper, U.S. Forest Service, Rocky Mountain Research Station

A Large-Scale Nutrient Addition Experiment in the Kootenai River, Idaho: Effects of Phosphorous on Water Chemistry, Algal Production, and Periphyton Taxonomy Genny Hoyle, Kootenai Tribe of Idaho

Use of Hydrated Lime to Reducing the Risks of Release of Invasive Species from Boats and Ballast Systems Laura Hughes, Amber Barenberg, Tasha Britton, and Charles Withers-Haley, University of Idaho

Quantifying the Rates of Hook Breakdown in Acidic Solutions Tony Lamansky, Mathew Belnap, and Erin Larson, Idaho Department of Fish and Game

Fish Habitat Committee: Providing Support and Information for Fisheries Professionals and Other Interested Parties, in the Management, Preservation, and Restoration of Aquatic Habitats Throughout Idaho.

Corey Lyman, USDA Forest Service; Stephanie Hallock, Coeur d'Alene Tribe; Dan Scaife, USDA Forest Service

Evaluating the Accuracy of Sibling Reconstruction Programs Using Steelhead SNPs Jesse McCane, Pacific States Marine Fisheries Commission

Determining the Maternal Origin of Juvenile $\boldsymbol{O}$. Mykiss in the Lapwai Basin, Idaho Alifia Merchant, University of Ohio School of Environment and Natural Resources

Status of Kootenai River White Sturgeon Population

Pete Rust, Idaho Department of Fish and Game

Phenotypic and Genetic Identification of Bull Trout X Brook Trout Hybrids in the South Fork of the Salmon River

Shiloh Ryker, Cascade Jr./Sr. High School

Environmental Factors Affecting Aquatic Invertebrate Production in Wilderness Streams of Central Idaho Matthew V. Schenk, Idaho State University

Genetic Stock Identification of Kelt Steelhead in the Yakima River Basin Across Multiple Years and Collection Times Jeff Stephenson, Columbia River Inter-Tribal Fish Commission

Evaluation of a Feed Exposure Challenge for Flavobacterium psychrophilum Kali A. Turner, University of Idaho

Sensitivity Analysis of Kokanee Egg-to-Fry Survival Estimates in Lake Pend Oreille, Idaho Steven L. Whitlock, University of Idaho

\section{6:30- ??:?? EVENING SOCIAL AND AUCTION!}

Location: Bays 1,2, and 3

Events include:

- Live and Silent Auction - Come prepared to spend! Win/purchase some great items. All proceeds go to support the Chapter!!

- Entertainment!! The AFS Fish Jam -Talent from within the Chapter! Everyone is welcome to participate. Bring your voices and/or instruments!!

- Appetizer buffet!! 
Friday, March 9

Session 5: Contributed Papers

Moderator: Malia Gallagher

Location: Bay 2

8:20-8:30 AM Announcements and Introduction to Session

8:30-8:50 Enforcing Fisheries Management Decisions; Idaho Dept. Fish and Game's Effort to Protect, Preserve, Perpetuate and Manage Idaho's Fisheries Resources Through Law Enforcement Eric Crawford, Idaho Department of Fish and Game

8:50-9:10 Monitoring Snake River Fall Chinook Salmon Spawning with a Remote Control Aircraft Brad Alcorn, Idaho Power Company

9:10-9:30 Enhanced Protection of a Bacterial Coldwater Disease Vaccine by Culturing in Iron Limited Media Amy Long, University of Idaho

9:30-9:50 An Evaluation of the Channel Catfish Fishery in Four North Idaho Lakes Kelly Carter-Lynn, Idaho Department of Fish and Game

9:50-10:20

Break (Bay 2)

Session 5: Contributed Papers (cont)

Moderator: Jenny Nalder

Location: Bay 2

10:20-10:40 Balancing Chinook Salmon and Kokanee in Coeur d'Alene Lake, Idaho Melo A. Maiolie, Idaho Department of Fish and Game

10:40-11:00 Brook Trout Diet Patterns During Summer Oxygen Depletion in Owhi Lake Using Stable Isotope Analysis and Lipid Extraction

Amy A. Martin, Washington State University

11:00-11:20 Age Structure and Growth Analysis of Bowfin in Lake Lindsay Grace, GA. Nick Porter, University of Idaho

11:20-11:40 Evaluation of the Effectiveness of Several Hook Types at Minimizing the Occurrence of Deep Hooking Stream Trout When Bait Fishing

Christopher L. Sullivan, Idaho Department of Fish and Game

11:40-12:00 Best Paper Awards

See you next year in Boise! Travel safely. 


\title{
Presentation Abstracts in Alphabetical Order
}

\author{
Monitoring Snake River Fall Chinook Salmon Spawning With A Remote Control Aircraft
}

\author{
Brad Alcorn, Phil Groves and Jim Chandler \\ Idaho Power Company \\ Presenter: Brad Alcorn, (208)388-5496, balcorn@idahopower.com
}

During the fall of 2011, we tested a new method for counting and estimating redds constructed by fall Chinook salmon (Oncorhynchus tshawytscha) in the lower Snake River. Our objectives were to explore a method that increases safety, reduces costs, and results in acceptable/useful data acquisition. We used a small radio controlled craft (a hexacopter), with flight properties that were attractive for our objectives. The hexacopter weighs approximately $1200 \mathrm{gm}$, has a diameter of $65 \mathrm{~cm}$, and stands $30 \mathrm{~cm}$ high. Our hexacopter carried a small video camera, weighing approximately $95 \mathrm{gm}$. The tilt of the camera mount can be remotely controlled; however, we generally collected data with the camera facing directly down. The hexacopter has several autonomous flight capabilities (maintaining a fixed position, returning to a "home" position, flying a series of waypoints); however, we manually controlled our unit during each flight. During flights we generally maintained an elevation of $30 \mathrm{~m}$ above the water surface. Using data from $1998-2010$, we chose a group of 17 index sites for our tests. These sites represent areas where consistent, high use has been documented. A simple regression model relating total number of redds at those sites to the total number of redds throughout the river was developed, and proved to be accurate. Each index site was surveyed once each week from 17 October through 6 December. It took approximately six to ten minutes to fly each site, and because of distance between sites, it took two days to conduct surveys each week. Video was recorded throughout each flight, and is presently being post-processed and compared against traditional survey methods (biologist's count from a helicopter). Final results will be presented; however, a preliminary assessment is that the hexacopter is a viable means of collecting accurate spawning site data.

\section{Evaluation of Artificial Markers for Monitoring Releases of Burbot (Lota lota) in the Kootenai River}

\author{
Neil Ashton and Ken Cain \\ University of Idaho \\ Presenter: Neil Ashton, University of Idaho, (208)885-7860, asht5445@vandals.uidaho.edu
}

Conservation aquaculture is part of a collaborative strategy to restore imperiled burbot (Lota lota) populations in the lower Kootenai River. Effective tagging methods are needed to monitor hatchery releases of juveniles, but a detailed assessment of tags suitable for burbot is currently absent from the literature. A preliminary short-term ( 28 days) experiment evaluated seven tags plus a control treatment for effects on fish survival, growth, and mark retention. The variety of artificial markers studied included fin clips, freeze brands, visible implant elastomer (VIE) and passive integrated transponder (PIT) tags. No significant differences were found in measured variables across all treatments, confirming these tested markers are harmless to juvenile burbot and exhibit retention of $99.4 \% \pm 0.3$ after one month. Subsequent ongoing research is evaluating long-term ( 365 days) retention of 16 tags of the same artificial variety, but with additional VIE colors and body locations. At 290 days post-tagging, the majority of tags have been retained at $90 \%$ or above. However, tag retention in four markers has dropped below 90\%: thoracic VIE green (83\%), dorsal fin clip (77\%), ventral VIE green (66\%), and dorsal freeze brand (0\%). Pectoral fin clips, ventral freeze brands, and fluorescent red VIE tags are exhibiting superior retention to their counterparts (dorsal fin clips, dorsal freeze brands, fluorescent green VIE tags). Early indications are that long-term tag retention for the tested variety of artificial markers will be significantly different and dependent upon tag type, color, fish body location, and tissue characteristics. 


\title{
Emerging Lessons: Unforeseen Consequences of Invasive Species for Stream-Riparian Food Webs and Ecosystem Processes
}

\author{
Colden V. Baxter, \\ Stream Ecology Center, Department of Biological Sciences, Idaho State University, \\ Presenter: Colden V. Baxter, (208) 251-5980, baxtcold@isu.edu
}

Species invasions can trigger a combination of direct and indirect changes in food webs that have consequences for native aquatic biodiversity and the functions of ecosystems, and some of these effects may be relatively unforeseen. In particular, an array of evidence has demonstrated that invasion of a species in one habitat can change fluxes of materials and organisms to adjacent or distant habitats, affecting native species and functions in those locations. Here I synthesize findings from a series of studies of invasive aquatic and terrestrial species that affect linked stream-riparian ecosystems. For example, in Japan, invading rainbow trout not only had negative effects on native char, but also increased streambed algae and reduced aquatic insect emergence, which, in turn reduced riparian spiders that depend on these prey. Similarly, brook trout that replace cutthroat trout in streams of the western U.S. cause reductions in emergence flux and spiders owing to their higher production and different foraging traits. Reciprocally, invasion of western U.S. riparian areas by Russian olive has altered stream organic matter budgets and nutrient dynamics, presumably via its ability to fix $\mathrm{N}_{2}$, and because its low-quality leaf litter is decomposed slowly and underutilized by native invertebrates and fishes. Moreover, many watersheds invaded by Russian olive are also experiencing an aquatic invasion by New Zealand mudsnails, and often the only fishes present capable of utilizing either of these invasive species as food are nonnatives such as carp, raising the potential for facilitation among multiple invaders. Strong effects of species invasions can be unforeseen, and may be driven by novel functional traits of invaders, trophic mismatches between invaders and native food webs, relatively subtle differences in behavior of invasive species versus natives they replace, and perhaps synergisms among multiple invaders.

\section{Seasonal Growth Rates, Smolting and Early Male Maturation in Hatchery Chinook Salmon Programs in the Columbia River Basin}

\author{
Brian Beckman, Don Larsen, Deb Harstad and Dina Spangenberg \\ NOAA Fisheries \\ Presenter: Brian Beckman, NOAA Fisheries, (206)860-3461, brian.beckman@noaa.gov
}

One of the major goals of hatchery programs releasing Chinook salmon smolts is adults returning from these releases. Among the factors that contribute to adult return rates are the degree of smolt development at release and the proportion of the released smolts that are actually maturing males (minijacks). Neither smolt development nor the proportion of males maturing at age 2 are genetically fixed; rather, growth and rearing in the hatchery may have profound effects on both smolting and maturation and the subsequent performance of the released smolts. We have monitored several different yearling Chinook salmon programs over the past decade, including both spring and summer Chinook salmon. Results from this work demonstrate that elevated growth rates during the autumn/winter promote early male maturation and that enhanced growth rates during the spring promote smolting. We have found that programs that are able to mirror the seasonal growth rates found in wild fish (low growth in autumn and winter, higher growth in spring - the wild fish template) generate high quality smolts (low rates of early male maturation, good smolt development in the spring). While not all programs may be able to mimic the seasonal growth patterns of 
wild fish, knowledge of how differences in seasonal growth rates affect smolt quality may guide programs to alter size targets and seasonal feeding guidelines to increase smolt performance.

\title{
Species-Wide Genetic Analysis of Westslope Cutthroat Trout
}

Daniel M. Bingham, Kristy Pilgrim, Kevin McKelvey, Michael K. Schwartz and Michael Young Rocky Mountain Research Station, Forestry Sciences Lab

Presenter: Daniel M. Bingham, (406)542-3255, daniel.bingham@umontana.edu

We analyzed 95 single nucleotide polymorphisms (SNPs) to determine the species-wide genetic population structure and major evolutionary lineages of westslope cutthroat trout. We detected significant genetic differentiation among major drainages and among samples within drainages. Neighbor-joining dendrograms grouped samples according to major river drainages, including the Clark Fork, middle Columbia, Missouri, Salmon, Spokane, and upper Columbia. Dendrograms also revealed similar clustering patterns to recently published microsatellite data. Such concordance across markers in genetic subdivisions strongly suggests that the evolutionary trajectory of cutthroat trout is distinct within drainages. This result also highlights the importance of recognizing separate lineages of cutthroat trout for conservation purposes. Similarity of our results with investigations using allozymes and microsatellites also provides evidence that SNPs are a valid marker choice for both population genetic and evolutionary studies.

\section{Distribution and Genetic Structure of a Needle in the Fragmented Haystack: The Tale of a Rare High-Desert Minnow, the Northern Leatherside Chub}

\author{
Jason Blakney, Janet Loxterman and Ernest Keeley \\ Department of Biological Sciences, Idaho State University \\ Presenter: Jason Blakney, (406)396-4055, blakjaso@isu.edu
}

The northern leatherside chub (Lepidomeda copei, NLSC), is a rare and very patchily distributed minnow species that was described as a distinct species in 2004. Extant populations currently inhabit streams reaches within the Salt River, Goose Creek and Pacific Creek drainages of the Snake River basin, portions of five subbasins within the upper and middle Bear River watershed as well as two tributaries to the Green River. Our objectives were to conduct a population genetic analysis across the species geographic range as well as to describe the distribution and relative abundance within the Snake basin. We compiled tissue samples from 975 NLSC from 27 streams representing nearly all known populations. Preliminary mtDNA analysis reveals NLSC populations are divided into two major clades. One clade includes haplotypes from the Salt River/Pacific Creek, as well as the Bear River and Green River watersheds. All haplotypes in the Goose Creek subbasin were unique to that drainage. In addition to the mtDNA analyses, we are investigating genetic diversity at nuclear microsatellite loci, which will provide insight into contemporary patterns of gene flow and genetic diversity. In conjunction with our genetic analyses, we are also comparing detection probabilities for three different sampling strategies to ascertain the most efficient method for sampling a rare species, such as the NLSC. To date, we have discovered new populations in Pole Creek (Goose Creek), Tincup Creek (Salt River) and Stump Creek (Salt River). Review of museum specimens also indicates that the species is present in four Snake River tributaries where we failed to detect leatheride chub; Blackfoot River (2002), Little Wood River (1897,1934), Owyhee River (1962) , Salmon Falls Creek (1962). 
Characterizing Juvenile Chinook Salmon Life History Variability in the Willamette Valley Using Otoliths and Scales

\author{
S. Bourret ${ }^{1}$, B.P. Kennedy ${ }^{1}$, C.C. Caudill ${ }^{1}$ and L. Borgerson ${ }^{2}$ \\ ${ }^{1}$ Department of Fish and Wildlife Resources, University of Idaho \\ ${ }^{2}$ Oregon Department of Fish and Wildlife \\ Presenter: Samuel Bourret, (208)885-4008, bour6715@vandals.uidaho.edu
}

Understanding the distribution, abundance and relative performance of life history types is critical for development of management strategies for juvenile Chinook salmon in the Willamette Valley Basin (WVB), and an important element of the Willamette Valley Biological Opinion. Recent analyses of screw trap data suggest that juvenile Chinook salmon life history strategies are variable within and among WVB populations, including traits that resemble both an ocean-type life history with subyearling emigration in summer or fall, as well as a stream-type life history with yearling emigration the following spring. We reconstructed the juvenile rearing and migratory patterns of a sample of natural origin adult Chinook salmon that returned to the Middle Fork Willamette Basin. Scale morphometric patterns and otolith isotope ratios $\left({ }^{87} \mathrm{Sr} /{ }^{86} \mathrm{Sr}\right)$ were used to characterize juvenile life histories and estimate juvenile size at freshwater emigration. We also used alkaline earth elements $\mathrm{Sr}, \mathrm{Ba}, \mathrm{Mn}, \mathrm{Mg}$, and $\mathrm{Ca}$ in otoliths and water, combined with otolith morphometric attributes, to discern movement and rearing of natural origin juvenile Chinook salmon in natal rearing (adult out-plant) tributaries and downstream project reservoirs. We found that a significant portion of sampled juvenile Chinook salmon had reared in project reservoirs and emigrated from freshwater at large sizes, which may provide a survival advantage to adulthood. Elemental water samples between the North Fork Middle Fork Willamette and Lookout Point reservoir were variable, and similar trends were found in otoliths from juveniles captured in each habitat. Preliminary results from analysis of otolith microstructure suggest increased growth in project reservoirs relative to natal rearing streams. Determining the juvenile rearing habitat and emigration ecology of these populations will enhance the understanding of the interaction between life history variation and anthropogenic disturbance and assist in developing appropriate management strategies.

\title{
Comparison of Juvenile Life History Strategies Exhibited by Steelhead within the Potlatch River Drainage, Idaho
}

Brett J. Bowersox and Timothy Copeland

Idaho Department of Fish and Game

Presenter: Brett J. Bowersox, (208)799-5010, brett.bowersox@idfg.idaho.gov

In Idaho, juvenile steelhead often leave natal streams to rear downstream. Evaluation of this life history strategy is important for assessing smolt production and freshwater survival; however this information has been limited between traps in natal streams and downstream dams. We used instream PIT-tag detectors to address this issue. We observed substantial differences in juvenile steelhead life history strategies exhibited between the eastern and western halves of the Potlatch River drainage. Age composition of juvenile outmigrants from Big Bear Creek (west side) and East Fork Potlatch River (east side) were much different with age-2 outmigrants (62-67\%) dominating Big Bear Creek and age-1 outmigrants (75-86\%) dominating East Fork Potlatch River during the 2009 and 2010 spring migration. The rate of active smolt outmigration from natal rearing areas was also different. Same year arrival rates to Lower Granite Dam during the 2009 and 2010 outmigration were $38-54 \%$ and 5-8\% for Big Bear Creek and East Fork Potlatch River respectively. By examining arrival rates to tributary and mainstem Potlatch River instream PIT-tag detectors we were able to establish migration characteristics and rearing strategy differences between the two drainages during the 2010 outmigration. We found juvenile fish captured at screw traps were detected on their associated tributary instream array at similar rates, $95 \%$ and $91 \%$ for Big Bear Creek and East Fork Potlatch River 
respectively. There were significant differences however, in arrival rates to the mainstem Potlatch River instream array with $78 \%$ and $18 \%$ of fish tagged at Big Bear Creek and East Fork Potlatch River screw traps arriving at that array the same year as tagging. Downstream rearing will affect survival of the East Fork Potlatch River group. The effect of subsequent year outmigrants needs to be accounted for when analyzing juvenile steelhead population dynamics.

\title{
Lifecycle Assessment Integrating Two or More Species to Improve Sustainability in Marine Aquaculture
}

\author{
Lubia Cajas Cano ${ }^{1}$, Christine M. Moffitt ${ }^{2}$ \\ ${ }^{1}$ Environmental Sciences Program and Department of Fish and Wildlife Resources \\ ${ }^{2}$ US Geological Survey, Cooperative Fish and Wildlife Research Unit \\ Presenter: Lubia Cajas Cano, (208)596-6733, lubiacajas@vandals.uidaho.edu
}

Marine based aquaculture systems have the potential to reduce the use of global scarce freshwater resources in food and fiber production. Like all agriculture systems, marine aquaculture has costs and benefits that must be analyzed. The lifecycle assessment (LCA) tool can be used to better understand usage and demand of natural and human resources and highlight opportunities to improve sustainability in the environmental, social and economic sectors. We used this framework to evaluate water and energy use, job security and safety, and economic input-output from two aquaculture systems: a monoculture species system and a multitrophic aquaculture system. The monoculture species system was a mussel farm in Washington State, and the multi-trophic production system was in British Columbia Canada. Our results emphasized the importance of considering environmental, social and economic factors in these evaluations. Our LCA analysis indicated an area for reducing the water footprints in the processing stage of production. The amount of fuel used during the farm stage of production was minimal when compared to the product distribution stage. The majority of expenses in the mussel farm reside in operations, with the second largest expense being labor and benefits. In worker interviews, we identified factors such as job safety and job security were highest in importance among executives and managers, but not for farm workers. With the growing global interest in increasing aquaculture production it is pivotal to evaluate costs and benefits of the integration of the multi-trophic production systems and to assess the optimal location of the production. Our results can help managers and regulators understand ways to optimize management practices, use of natural ecosystem services and provide better support for the marine ecosystem and local communities.

\section{An Evaluation of the Channel Catfish Fishery in Four North Idaho Lakes}

\author{
Kelly Carter-Lynn, Mark Liter and Brian Hammond \\ Idaho Department of Fish and Game \\ Presenter: Kelly Carter-Lynn, (208)769-1414, kelly.carter-lynn@idfg.idaho.gov
}

Little is known about channel catfish populations in north Idaho lakes because they are difficult to sample. While information exists on basic biology of channel catfish, population assessments to assist in the management of channel catfish are needed. We evaluated baited hoop nets as a tool to sample channel catfish; we evaluated channel catfish size structure and condition. Three hundred twenty nine channel catfish were tagged using Carlin dangler tags to estimate angler exploitation. Channel catfish were sampled with baited tandem hoop nets set in a 3 net series (HNS) in Hauser, Fernan, Cocolalla and Jewel lakes. A total of 3802 channel catfish were captured using HNS baited with cheese logs and soybean cake. Having found nearly identical catch rates, we recommend soybean cakes as the preferred bait type. Length frequencies were similar between Hauser, Fernan, and Cocolalla Lakes and ranged from 181 to $558 \mathrm{~mm}$ total length (TL).We did not capture any channel catfish larger than $558 \mathrm{~mm}$ TL; size biases for large fish may exist. 
Channel catfish mortality was observed on only one occasion ( $0.01 \%$ of total catch) due to longer than normal handling time. By-catch mortality was typically less than $1 \%$ and consisted mostly of bluegill, tench, pumpkinseed and black crappie. The majority of channel catfish sampled were above the minimum stock length $(280 \mathrm{~mm})$ with few individuals above quality length $(>410 \mathrm{~mm})$ sampled. On average, channel catfish sampled weighed above or near $100 \%$ of the standard weight and condition $\left(\mathrm{W}_{\mathrm{r}}\right.$ ) varied little by length category. The overall mean $W_{r}$ of all fish was 96 in Jewel and Fernan lakes, 105 in Hauser Lake and 107 in Cocolalla Lake. We recommend sampling in July prior to annual stocking to avoid complications of recently stocked fish and provide a more accurate assessment of the population for the fishing season.

\section{Trends in Length at Age and Age at Maturity of Two Stocks of Hatchery Chinook Salmon and Adjacent Natural Populations in Idaho}

John Cassinelli and Brian Leth

Idaho Department of Fish and Game

Presenter: John Cassinelli, (208)465-8404, john.cassinelli@idfg.idaho.gov

Increased numbers of returning hatchery-origin Chinook salmon (Oncorhynchus tshawytscha) jacks to the Columbia Basin in recent years have raised concerns about trends in the age at maturity of hatchery stocks. We investigated sex-specific mean age, age distribution, mean length and length at age, over time, for two stocks of Idaho hatchery-origin Chinook salmon from the McCall and Sawtooth fish hatcheries and compared these metrics to adjacent natural populations. In general, both hatchery and natural populations are trending towards younger and smaller fish, but natural populations are consistently larger at age and older at return than hatchery populations. We also evaluated hatchery broodstock protocols, specifically the proportions of the broodstocks that were composed of jacks, and the relationship to the age structure of the returning progeny. For both hatchery populations, there is no significant correlation between an increased proportion of jack males spawned and an increased proportion of males returning as jacks. It is likely that hatchery practices have contributed to decreased mean age and size of hatchery and potentially adjacent natural populations. However, these characteristics also appear to be linked to environmental conditions and the observed trends may be more related to natural adaptations to a changing environment. The extent to which resource managers should strive to reverse these apparent trends is a difficult question. Continued monitoring of these metrics over time, along with additional research, are necessary to gain a better understanding of the drivers behind these trends and to aid in making informed management decisions.

\section{Declining Native Fish Composition in the Middle Snake River and the Importance of Spring Habitats.}

James Chandler, Tracy Richter, Mike McLeod, John Anderson, David Blew, Janak Timilsena and Jon Bowling Idaho Power Company

Presenter: James Chandler, (208)388-2974, JChandler@idahopower.com

Fish community composition and relative abundance has been monitored in the Snake River from American Falls Dam (RM 715) to Hells Canyon Dam (RM 247) at 5 year intervals from 1990 - 2010. During that 20 year period, significant declining trends for native fish species and significant increasing trends for non-native fish species have occurred throughout the Snake River with the exception of the those sections of the Snake River strongly influenced by a high volume of spring discharge from the Snake River aquifer near Hagerman, Idaho. During this same time interval, flow volumes in the Snake River basin have been significantly declining as has the volume of spring discharge into the Snake River. Temperature has not demonstrated significant trends in the Snake River, with the exception of the river associated with spring discharge, where a significant increasing trend is occurring, possibly related to declining spring flows. Trends in fish abundance suggest that the spring influenced reaches of the Snake River are important areas for maintaining native fish assemblages 
in the Snake River. This emphasizes the need to protect spring habitats and the Snake River aquifer in the face of uncertainty related to climate change and increasing pressure on the use of water in the Snake River basin.

\title{
The Surprising History of 'Biological Invasions'
}

\author{
Matt Chew \\ University of Arizona \\ Presenter: Matt Chew, (480)965-8422, mchew@asu.edu
}

Introduced populations are a hallmark of human civilization. The process of anthropochory, the dispersal of biota via human agency, has been ongoing for millennia. Its outcomes are sometimes celebrated and sometimes deplored because the criteria of desirability are remarkably flexible and ad hoc. Introduced species have been studied and discussed for centuries, and even the most current work of invasion biology unwittingly relies on pre-Victorian ideals for its justification and theoretical structure. This presentation reintroduces introduced species using some familiar cases in unfamiliar ways, and introduces some historical figures you really need to meet.

\section{A Critical Assessment of the Ecological Assumptions Underpinning Compensatory Mitigation of Salmon Derived Nutrients}

\author{
Scott F. Collins ${ }^{1}$, Colden V. Baxter ${ }^{1}$ and Amy M. Marcarelli ${ }^{2}$ \\ ${ }^{1}$ Idaho State University \\ ${ }^{2}$ Michigan Technological University \\ Presenter: Scott F. Collins, (208)380-2376, collscot@isu.edu
}

Stream and river restoration efforts have grown dramatically over recent decades, with estimates of $>\$ 1$ billion spent on the protection, preservation, and restoration of lotic environments. Annually, millions of dollars are appropriated to Pacific salmon (Oncorhynchus spp.) recovery efforts within the Columbia River and its tributaries, often through compensatory mitigation programs with the intent of offsetting lost ecological services provided by salmon. The concept of increasing freshwater productivity through nutrient additions is not novel, yet this approach is being increasingly applied to mitigate for reductions or loss of returns of salmon by replacing the delivery of marine-derived nutrients to streams. Here we critically evaluate some of the key ecological assumptions underpinning the use of such mitigation tools. These assumptions include: (1) mitigation is needed to replace nutrients lost with diminished salmon return and to stimulate primary and invertebrate production in streams, (2) food resources in rearing habitats limit populations of salmon and some resident fishes, and (3) nutrient mitigation mimics the functional roles of salmon. First, though seemingly straightforward, we show that assumption 1 may require qualification based on a more complete understanding of nutrient cycling and the concept of nutrient limitation in streams. Second, we evaluate the empirical evidence supporting assumption 2, and find it has been only weakly tested. Third, assumption 3 is called into question by an array of evidence which points to the multi-faceted role played by spawning salmon, including redd-building disturbance, nutrient recycling by live fish, and consumption by terrestrial predators - none of which are mimicked by standard nutrient mitigation approaches. Additional evidence suggests that the role of salmon may vary with environmental context. On the basis of our assessment, we offer caution in the application of nutrient mitigation as a management tool and recommendations regarding research priorities aimed at further evaluating its scientific foundation. 


\title{
Pend Oreille River Fisheries Management: The Past, Pike, and Future
}

\author{
Jason M. Connor \\ Kalispel Tribe of Indians \\ Presenter: Jason M. Connor, (509)447-7285, jconnor@knrd.org
}

Prior to hydroelectric development, the Pend Oreille River was dominated by native resident salmonids, minnows, and suckers. Widespread introductions of non-native species, coupled with habitat alteration lead to a precipitous decline of salmonids and dominance by yellow perch, pumpkinseed, and tench in Box Canyon Reservoir. By the 1980's, largemouth bass was the only significant sport and subsistence fishery in the reservoir. Enhancement of the largemouth bass population through habitat improvement and supplementation has been a priority for the Kalispel Tribe since 1995. Northern pike, illegally introduced to the Clark Fork River, Montana immigrated to the lower Pend Oreille prior to 2004. The population has rapidly expanded in number and range and threatens to undermine current and future recovery efforts for bull trout and westslope cutthroat trout, as well as the persistence of other native species and sport fish. Northern pike also pose significant risks to the anadromous fisheries of the Columbia River if left to emigrate downstream. The Kalispel Tribe, in cooperation with the Washington Department of Fish and Wildlife, plan to implement measures to reduce the abundance of northern pike by 87\% in Box Canyon Reservoir beginning in 2012.

\section{Enforcing Fisheries Management Decisions; Idaho Department of Fish and Game's Effort to Protect, Preserve, Perpetuate and Manage Idaho's Fisheries Resources Through Law Enforcement}

\author{
Eric Crawford \\ Idaho Department of Fish and Game \\ Presenter: Eric Crawford, (208)669-1106, eric.crawford@idfg.idaho.gov
}

The Idaho Dept of Fish and Game's Enforcement Bureau plays a critical role in the management of people as they recreate in outdoor activities associated with Idaho's fish and wildlife resources. This presentation is an overview of the activities by Conservation Officers of the Idaho Dept. of Fish and Game that relate to management and protection of Idaho's fishery resources. The 117 conservation officers are perhaps the most visible component of the Idaho Dept. of Fish and Game to the recreating public. Conservation Officers are charged with the enforcement of Idaho Code Title 36, which deals with laws associated with the taking of fish and wildlife. In addition to their enforcement role, Conservation Officers conduct a great deal of public outreach and education. Collectively, Conservation Officers contact more hunters and anglers and disseminate more information than all other Department employees combined. This extensive interaction with the public provides a unique opportunity for fisheries professionals by potentially bolstering support for management decisions. During the last three years conservation officers contacted 147,443 total anglers, 17,429 steelhead anglers, 10,767 chinook anglers and made an additional 253,367 nonenforcement contacts. In addition to law enforcement duties, officers assisted fisheries biologists and managers with information and education ranging from new rules awareness to angler recruitment. Examples of information dissemination include action plans on the South Fork Snake River, Snake River, and the Coeur d'Alene River. In the South Fork Snake River officers conducted concentrated patrols to inform anglers of the department's effort to increase rainbow trout and hybrid cutthroat/rainbow trout harvest while eliminating Yellowstone cutthroat trout harvest. On the Snake River an action plan was conducted to detect the illegal harvest of white sturgeon. In the Coeur d'Alene River officers initiated an angler creel survey to evaluate angler's level of knowledge regarding Westslope cutthroat trout regulations and to evaluate their ability to identify hybrids. Officers oversee or are involved in many other activities to promote responsible fishing. In the Challis area officers and local biologists have organized the annual Free Fishing Day, which attracts over 100 children. Fisheries professionals can benefit from an understanding of the role Conservations Officers play, and a recognition of the opportunity that role presents in communicating with the public. The hope is that 
this presentation furthers that understanding and stimulates communication between fisheries and enforcement staff in the development of Fisheries Enforcement Action Plans and setting shared goals in the ongoing protection of Idaho's rich fisheries resources.

\title{
Hydrologic Regime Influence on Age-1 Walleye Recruitment in Lake Roosevelt, Columbia River
}

\author{
Benjamin K. Cross and Barry C. Moore \\ Washington State University School of the Environment \\ Presenter: Benjamin K. Cross, (320)296-1386, Benjamin.Cross@wsu.edu
}

Hydrologic regime influences on age-1 walleye (Sander vitreus) recruitment in Lake Roosevelt, Washington were examined to predict and understand recruitment drivers using data from the Lake Roosevelt Fisheries Evaluation Program. Limnological and hydrological data from 1998 to 2002 was investigated and related to walleye age-1 CPUE data from 1999 to 2003. Inflow volumes from the Columbia River were significantly related to water retention time in Lake Roosevelt $(P=0.0015)$. Regression analysis identified walleye age-1 CPUE being significantly related to inflow volumes, water retention time, and July Daphnia sp. biomass of the year prior $(P=0.0020, P=0.0020$, and $P=0.0180$ respectively), with Columbia River inflow volumes explaining the most variance in the data (adj. $R^{2}=0.9633$ ). July Daphnia $s p$. biomass was significantly related to both inflow volumes and water retention time $(P=0.0205$ and $P=0.0240$ respectively). Inflow volumes of the Spokane River, the major spawning tributary, were not significantly related to walleye age-1 CPUE $(P=0.1549)$. Consequently, flow data was not influencing walleye spawning success to the point in which it would limit age-1 recruitment. Moreover, walleye age-1 recruitment is increased by lower inflows, creating longer water retention times which lead to increased July Daphnia sp. biomass. Age-1 walleye recruitment appears to be driven by food availability and other environmental factors controlled by inflows.

\section{Suppression of Cannibalism During Larviculture of Burbot (Lota lota maculosa) Through Size Grading}

Josh Egan ${ }^{1}$, James M. Barron ${ }^{1}$, Nathan R. Jensen ${ }^{2}$, Paul J. Anders ${ }^{2}$, Susan C. Ireland ${ }^{3}$ and Kenneth D. Cain ${ }^{1}$

${ }^{1}$ University of Idaho

${ }^{2}$ Cramer Fish Sciences

${ }^{3}$ Kootenai Tribe of Idaho

Presenter: Josh Egan, (208)885-5734, egan6168@vandals.uidaho.edu

Survival and cannibalism of burbot larvae and metamorphosing larvae reared for 15 days following a grading event were compared to non-graded control groups. In larvae (11.8 $\pm 2.4 \mathrm{~mm}$ total length), grading was immediately effective in producing size distinction as the passed group was significantly narrower and shorter than the retained group. Retained fish had a significantly lower coefficient of variation of length than control fish, indicating grading reduced size heterogeneity. Grading significantly increased survival over the control, averaging $74.3 \%$ in the passed fish and $93.3 \%$ in the retained fish compared to $59.3 \%$ in the control. Additionally, grading significantly reduced cannibalism in graded groups relative to the control, which averaged $14.3 \%$ in the passed fish and $1.0 \%$ in the retained fish compared to $29.0 \%$ in the control. However, grading did not affect total length, width, or coefficient of variation in metamorphosing larvae $(21.0 \pm 2.4 \mathrm{~mm}$ total length), nor did it improve survival or reduce cannibalism compared to the control. This study provides initial evidence that size grading can be an effective method to suppress cannibalism in larval burbot prior to the onset of significant cannibalism. 


\title{
A Long-Term Comparison of Yellowstone Cutthroat Trout Abundance in Idaho
}

\author{
Steven Elle, Kevin Meyer, Brett High and Arnie Brimmer \\ Idaho Department Fish and Game \\ Presenter: Steven Elle, (208)465-8404, steve.elle@idfg.idaho.gov
}

\begin{abstract}
We compared etimates of population abundance for Yellowstone cutrhoat trout Oncorhynchus clarki bouvieri obtained by electrofishing 77 stream segments across southeaster Idaho in the 1980's, 1999-20000 and 2010-2011 to test whether populations of Yellowstone cutthroat trout had changed. Sites samples in the 1980 's were relocated for subsequent sampling by using maps and photographs or by finding original siteboundary stakes, so that the same reach of stream was sampled during each period. Overall, population estimates declined by approximately $25 \%$ from $1999-2000$ through $2010-11$. The densities had remained relatively stable from the original sampling in the 1980's through the 1999-2000 sample period. During the past 10 years cutthroat have faced some major challenges including extended drought conditions across southeast Idaho, increasing pelican predation in the Blackfoot River Drainage and rainbow integression in the South Fork Snake and Teton rivers. Despite the declines in average population densities, there is reason to believe we may see improvement over the coming years.
\end{abstract}

\section{Evaluating and Addressing Impacts of Non-Native Fish Species Across Life-Stages of Adfluvial Westslope Cutthroat Trout in the Coeur d'Alene Basin}

\author{
Jon Firehammer \\ Coeur d'Alene Tribe \\ Presenter: Jon Firehammer, (208)686-7037, jfirehammer@cdatribe-nsn.gov
}

Over the past 15 years, the Coeur d'Alene Tribe's Fisheries Program has been implementing measures to recover adfluvial westslope cutthroat trout (WCT) populations in Benewah and Lake creeks in the Coeur d'Alene Basin. As a component of our recovery program, assessments have been conducted to examine the impacts of non-native fish species on WCT in stream environments and in Lake Coeur d'Alene. To address population-level impacts in spawning habitats, an analysis was recently conducted to describe the extent of hybridization between WCT and rainbow trout. Generally, results indicated that hybridization is rare with low rates of genetic introgression (i.e., $\leq 3 \%$ ); however, there was evidence of recent hybridization events in certain Benewah tributaries. These results may be attributed to escapees from private ponds, and could be mitigated for by offering the opportunity for triploids to be stocked. Our program has also been engaged in a brook trout suppression program in the upper Benewah watershed since 2004 to minimize impacts to cutthroat trout during stream rearing periods. Though our strategy of annually removing fish has not changed, we have recently modified our tactics. Since 2009, removal efforts have been concentrated within a reach that has been considered most suitable for successful brook trout reproduction, with temporary barriers also installed to prevent access to this reach. Since the adoption of this tactic, CPUE and percent YOY of brook trout removed, in addition to expended crew effort, have markedly declined. Our program also initiated a tagging program in 2005 to examine whether survival rates of WCT during lake residence is limiting population recovery. To date, less than $2 \%$ of juveniles tagged during their outmigration have returned to spawn. These results have prompted a collaborative study with the University of Idaho to evaluate the consumptive impacts of northern pike and smallmouth bass on WCT. 


\title{
Databasing Data to Improve Understanding of Fish Ecology and Management Uncertainties
}

\author{
Alexander K. Fremier ${ }^{1}$, Chris Caudill ${ }^{1}$, Dana Weigel ${ }^{2}$, Brian Kennedy ${ }^{1}$ and Michael Newsom ${ }^{2}$ \\ ${ }^{1}$ University of Idaho \\ ${ }^{2}$ U.S. Bureau of Reclamation \\ Presenter: Alexander K. Fremier, (208)885-6405, afremier@uidaho.edu
}

Increasingly ecological issues have to be addressed at larger spatial and temporal scales. Managing our environment, therefore, will require novel approaches that efficiently integrate data across local projects and through time. Despite the increase in management complexity, systematic coordination of data collection and data management are only in the beginning stages. With efficient data flows and coded analysis tools, researchers and managers will become more effectual at processing data, both for an individual project as well as for across project analyses.

In this project we are designing a platform for data management and analysis to improve data access and analysis, both at the site scale and for meta-analyses across the Columbia River Basin. We are developing an analytical framework and data flow to answer key management questions in the basin and link data collection and results. The project builds on existing data and modeling efforts in the CRB with an initial pilot project in the Methow River Basin of Washington State, in close coordination with the USGS Columbia River Research Laboratory.

The project integrates data and analysis procedures to assist biologists, statisticians and modelers. The software framework synthesizes and standardizes data for databases, including PIT-tag data (PITAGIS - fish movement, fish size and species), environmental data (stream flow, temperature, channel dimensions), and stream community data (species data). These data sources are linked spatially and temporally by a data harvester and linking tool. Standardized analyses are coded into a data analysis tools with the ability to output data to stand alone modeling programs. Linked data sources and standardized data analysis tools will help researchers and managers quickly access data to understand key components of the system. In addition, this toolset will help identify data gaps and provide strategies for improved monitoring and scientific efforts.

\section{Seven Years of Nutrient Addition to Restore Fisheries in the Kootenai River, Idaho}

\author{
Cathy Gidley ${ }^{1}$, Charlie Holderman ${ }^{2}$ \\ ${ }^{1}$ Idaho Department of Fish and Game \\ ${ }^{2}$ Kootenai Tribe of Idaho \\ Presenter: Cathy Gidley, (208)769-1414, cathy.gidley@idfg.idaho.gov
}

The Kootenai River, Idaho underwent a reduction in the amount of nutrients available for primary productivity since Libby Dam went into operation in the early 1970s. The dam acts as a nutrient sink whereby nutrients are bound to the sediments in the reservoir. Populations of burbot and white sturgeon as well as kokanee and trout were depressed. In 2005, the Kootenai Tribe of Idaho in conjunction with Idaho Fish and Game began adding liquid, inorganic phosphorous near the Idaho/Montana border in order to stimulate productivity at lower trohpic levels and ultimately improve fisheries. We added ammonium polyphosphate (10-34-0) to the river to achieve a of total dissolved phosphorus (TDP) concentration of 3.0 ug $\mathrm{L}^{-1}$, during the growing season from 2005-2011. After seven years of nutrient addition, we have seen improvements at multiple trophic levels. Total chlorophyll accrual rates $\left(\mathrm{ug} \cdot \mathrm{cm}^{-2} \cdot \mathrm{day}^{-1}\right.$ ) and mean algal biomass are significantly higher in treatment sites than control sites. Post nutrient addition, diatoms have increased, whereas blue-green algae have decreased. Macroinvertebrate response was similar, showing an increase in abundance and biomass post nutrient addition as well as an increase in species richness. Overall fish abundance and biomass in the treatment reach has increased, post nutrient addition as well. A population estimate conducted in 2011 showed a nearly two-fold increase in mountain whitefish, a five-fold increase in 
largescale sucker, and a $1 \frac{1}{2}$ increase in rainbow trout since 2004 , prior to nutrient addition. These three species have also shown some increases in relative weight and growth. We plan to continue to add nutrients to the Kootenai River and in conjunction with habitat improvement projects currently underway, to continue to aid in the restoration of fisheries.

\title{
The Role of rpoB Mutation in Rifampicin Attenuation of Flavobacterium psychrophilum
}

\author{
Karol Gliniewicz ${ }^{1}$, Karen Plant ${ }^{2}$, Scott E. LaPatra ${ }^{3}$, Kenneth Cain ${ }^{2}$, Kevin R. Snekvik ${ }^{1,5}$, Benjamin R. LaFrentz ${ }^{4}$ and \\ Douglas R. Call ${ }^{1}$ \\ ${ }^{1}$ Veterinary Microbiology and Pathology, Washington State University, Pullman, WA \\ ${ }^{2}$ Fish and Wildlife Resources, University of Idaho, Moscow, ID \\ ${ }^{3}$ Clear Springs Foods, Inc., Buhl, ID \\ ${ }^{4}$ USDA-ARS Aquatic Animal Health Research Unit, Auburn, AL \\ ${ }^{5}$ Washington Animal Disease Diagnostic Laboratory, Washington State University, Pullman, WA \\ Presenter: Karol Gliniewicz, (509)715-9353, karol@vetmed.wsu.edu
}

Flavobacterium psychrophilum is the causative agent of bacterial coldwater disease (CWD) in salmonids. Disease outbreaks usually occur when the water temperature is between $3-15^{\circ} \mathrm{C}$ and mortalities may exceed $50 \%$. Presently there are no licensed vaccines against CWD and treatment with antibiotics is not always effective due to emerging resistant strains. Recently, a fully attenuated strain of $F$. psychrophilum (CSF259.93) was obtained by passage on rifampicin-containing agar plates and immunization trials demonstrated protection of fish against challenge with strain CSF-259.93. Although there are other rifampicin-attenuated strains serving as live vaccines against several bacterial diseases the exact mechanism of rifampicin attenuation is unknown. Our work demonstrated that the attenuated strain (259-93B.17) has a mutation in the $r p o B$ gene that corresponds with resistance to rifampicin, and $2 \mathrm{D}$ gel electrophoresis and mass spectrometry demonstrated that the 259-93B.17 strain has an altered proteome with at least 13 differences relative to the wild-type CSF-259.93 strain when cultured in vitro. RpoB encodes for a beta subunit of RNA polymerase, an enzyme that is a key player is bacterial gene expression and the mutation can lead to altered function of the polymerase and induce changes in protein synthesis. However, whole genome sequencing of rifampicin-attenuated strain revealed numerous point mutations in different genes, as compared to the virulent strain. While the exact mechanism responsible for altered protein synthesis and attenuation have not been identified the research is under way to assess the role of $r p o B$ point mutation in attenuation of $F$. psychrophilum.

\section{Estimating Rates of Pelican Predation on Yellowstone Cutthroat Trout in the Upper Blackfoot River System}

\author{
Matt T. Green and Ernest R. Keeley \\ Idaho State University \\ Presenter: Matt T. Green, (208)251-0197, greemat3@isu.edu
}

Recent increases in piscivorous migratory bird populations and their impacts on fish populations have created conservation concerns for some populations. These impacts can be especially dramatic in situations where native fish are exposed to increasing bird populations. Such is the case with American white pelicans preying on Yellowstone cutthroat trout in the upper Blackfoot River system of southeast Idaho. In this study we used both radio telemetry and passive integrated transponder (PIT) tagged fish to estimate total pelican predation on Yellowstone cutthroat trout within the Blackfoot River system of southeast Idaho. Eight-eight adult cutthroat trout were radio-tracked in the upper river between 2010 and 2011. With tracking and tag recoveries, we determined minimum predation rates between 17 and 20 and upper predation rates between 28 and 49 percent. We also PIT tagged a total of over 1,350 cutthroat trout during the spring and summer of 
2010 and 2011. By scanning nesting islands for fish PIT tags that pelicans had consumed we estimated predation rate between 36 and 70 percent on juvenile cutthroat trout and between 6 and 36 percent for larger fish in the upper river. We plan to use these data to model how such rates of predation may influence the population dynamics of cutthroat trout in the upper Blackfoot River.

\title{
Effects of Initial Feed Timing on Triploid Rainbow Trout Fry at Grace Fish Hatchery
}

\author{
Beau J. Gunter, Martin Koenig, Bryan Grant and Eric Pankau \\ Idaho Department of Fish and Game, Grace Fish Hatchery \\ Presenter: Beau J. Gunter, (208)427-6364, beau.gunter@idfg.idaho.gov
}

The timing of initial feeding for trout fry varies greatly among hatchery professionals. Literature pertaining to initial feeding time of trout fry also varies with a wide range of recommendations provided for initial feed timing. Managers at Grace Fish Hatchery sought to reduce the variability of initial feed timing for triploid rainbow trout (Oncorhynchus mykiss) fry. The purpose of this study was to determine if there is a number of days post hatch to begin feeding triploid rainbow trout fry where they will experience the least mortality and most favorable growth factors. Treatment groups of triploid rainbow trout fry were fed for 30 days with initial feeding times of $13,15,17,19,21$ and 25 days post hatch on $12.2^{\circ} \mathrm{C}$ water. Variations in mortality, condition factor, size and feed conversions between initial feed times were evaluated. The results of this study not only provide fish culturists at Grace Fish Hatchery with the optimal number of days post hatch to begin feeding triploid rainbow trout fry, but they also eliminate the variability that is common among hatchery professionals in regards to initial feed timing of triploid rainbow trout.

\section{Prioritizing Restoration Activities in Two Watersheds of the Coeur d'Alene Subbasin to Improve Habitat for Westslope Cutthroat Trout}

\author{
Stephanie Hallock and Angelo Vitale \\ Coeur d'Alene Tribe Fisheries Program \\ Presenter: Stephanie Hallock, (208)686-0701, shallock@cdatribe-nsn.gov
}

A fundamental goal of the Coeur d'Alene Tribe Fisheries Program is to identify restoration needs in areas that have the greatest potential to improve habitat and translate into positive biological responses to recover depressed native cutthroat trout populations. We utilized previous watershed assessments and data from our status and trend monitoring to aid in the identification and prioritization of restoration actions. First, we developed objectives and criteria for describing the relative degree of impairment for a variety of watershed processes including sediment delivery, flood hydrology, riparian and channel function, water quality, and biological productivity. Watershed assessments and monitoring data were then used to assign a relative impairment ranking for each of these processes to three sub-basins in Lake Creek and nine sub-basins in Benewah Creek. The combined impairment rankings were used to assign a relative impairment score, which permitted the identification of those sub-basins that should be prioritized for restoration. For each high priority sub-basin, a list of projects was then developed with the intent of addressing the highlighted impairments. Projects were scored based on several criteria including the degree to which the action addresses watershed processes, the uncertainty associated with projected outcomes, and how the project accommodates local socioeconomic goals. Total scores were then used to further differentiate projects that were considered to have the greatest potential in achieving restoration goals. A total of 105 projects were identified, affecting $41.1 \mathrm{~km}$ of stream habitats. We provide an example of how we anticipate implementing these projects and discuss some of the implications for conducting effectiveness monitoring. 


\title{
Effects of Wildfire and Debris Flows on Downstream Insect Fluxes and Consequences for Drift - Feeding Fish in Recipient Confluence Habitats
}

\author{
Hannah E. Harris, Colden V. Baxter and John M. Davis \\ Idaho State University \\ Presenter: Hannah E. Harris, (208)282-2139, harrhan2@isu.edu
}

Because of increased light flux associated with reduced canopy cover, large-scale wildfires and subsequent debris flows may increase headwater stream productivity. We predicted that these potential positive effects of disturbances might increase downstream insect drift from headwater streams, subsequently benefiting downstream consumers in main-stem confluence habitats. We sampled export from 15 tributaries of the East Fork of the South Fork Salmon River in central Idaho ( 5 unburned, 5 that burned in 2007, and 5 that burned and then experienced a subsequent debris flow) and compared abundance and biomass of drifting insects in summer 2010 and 2011. We also conducted snorkel surveys along $100 \mathrm{~m}$ reaches to determine the extent to which disturbance history influences selection of confluence habitat by drift feeding fish. Finally, we conducted an experiment in which drifting insects were removed from tributary export with $250 \mu \mathrm{m}$ nets and fish behavior and abundance was monitored in main-stem confluence habitats pre- and post-drift depletion. Drifting insect abundance and biomass were similar in both types of burned streams, but were still 2-3 times higher than in unburned streams. In all cases, fish selected for confluence habitats in greater proportion than their availability and this habitat preference was strongest for confluences with either type of burned streams. When comparing responses pre- and post-drift depletion, fish abundance in confluence habitats did not decrease post-depletion, but the rates of feeding attempts and agonistic behaviors did decrease. In addition, a comparison of fish behavior in confluence and similar non-confluence habitats revealed that agonistic behavior rates were higher in confluence habitats. The combination of such evidence indicates that tributaries affected by wildfire and / or debris flows may represent important sources of insect production and that their confluence habitats may be particularly profitable for drift-feeding fish.

\section{A Life Cycle Modeling Approach to Life History Evolution in a Spatially Structured Population of Fall Chinook Salmon}

\author{
Jens Hegg ${ }^{1}$, Rich Zabel ${ }^{2}$, Paul Chittaro ${ }^{2}$ and Brian Kennedy ${ }^{1}$ \\ ${ }^{1}$ Department of Fish and Wildlife Sciences, University of Idaho, Moscow, ID \\ ${ }^{2}$ Fish Ecology Division, Northwest Fisheries Science Center, National Marine Fisheries Service \\ Presenter: Jens Hegg, hegg1432@vandals.uidaho.edu
}

Anthropogenic change, particularly hydropower development, has significantly altered the migration corridor and available spawning habitat of Snake River fall Chinook salmon, resulting in selective pressures substantially different from those experienced historically. Consequently, this population has undergone major changes in juvenile life history expression within just a few generations. Notably, a large proportion of the population has adopted a life history where juveniles migrate as yearlings compared to the historical norm of subyearling migration. Previous work has shown that the yearling life history is spatially structured within the spawning areas and may be correlated to the temperature of the spawning streams. In addition, life cycle models have indicated that the yearling life history may confer higher fitness than other life history strategies. We expand upon previous modeling by incorporating detailed information derived from otoliths. In particular, the combination of otolith microchemistry and microstructure provides information on growth rates in alternative habitats (rearing, overwintering, estuary and ocean) and the timing of movement between habitats. This approach allows us to explore the fitness of each life history strategy in the context of the spatially explicit environmental factors that may be influencing this population shift. It also allow us to assess how key life history traits (e.g., timing of ocean entry) may influence fitness. Ultimately, these 
methods will inform our understanding of how mitigation actions can improve the survival of salmonids within spatially variable habitats.

\title{
Supportive Breeding Boosts Natural Population Abundance Without Inflicting Negative Fitness Impacts on Wild Chinook Salmon in Johnson Creek, Idaho
}

\author{
Maureen A. Hess ${ }^{1}$, Craig Rabe ${ }^{2}$, Jason Vogel ${ }^{2}$, Jeff J. Stephenson ${ }^{1}$, Doug Nelson ${ }^{2}$ and Shawn R. Narum ${ }^{1}$ \\ ${ }^{1}$ Columbia River Inter-Tribal Fish Commission \\ ${ }^{2}$ Nez Perce Tribe
}

Presenter: Maureen A. Hess, (208)837-9096 ext. 1117, hesm@critfc.org

Supportive breeding programs for salmonids are commonly used to boost the size of populations at risk to extinction. While programs strive to minimize negative genetic impacts to wild fish, theoretical and empirical case studies have found evidence for reduced fitness of hatchery-reared fish when they are allowed to reproduce in the wild. This study is the first to evaluate lifetime fitness of Chinook salmon in a supplementation program (Johnson Creek, ID) at the initiation of supportive breeding, rather than after decades of confounding management practices. Pedigrees of two complete generations were tracked with molecular markers to investigate demographic and genetic impacts of supplementation to a natural population. Results show a significant demographic boost to the population from supplementation. On average, hatchery-reared fish produced 6.9 times more offspring and 2.0 times more grand-offspring than naturally reproducing fish. Additionally, we found limited evidence that hatchery-reared fish had significantly lower fitness than their wild-origin counterparts. Relative (to wild) reproductive success (RRS) of hatcheryreared fish $(\mathrm{H})$ that mated in the wild were generally equivalent to those between wild parents $(\mathrm{W})$, with $\mathrm{HxH}$ and $\mathrm{HxW}$ crosses having overall RRS of $0.92(p=0.95)$ and $1.07(p=0.89)$, respectively. We conclude that fish chosen for hatchery rearing did not have a negative impact on the fitness of wild fish by mating with them for a single generation. Results suggest that supplementation following similar management practices (e.g. 100\% in-basin, wild-origin brood stock) can successfully boost population size without incurring negative impacts to the fitness of wild populations.

\section{Using Multiple Sonar Deployments to Improve Run-Size Estimates of Anadromous Fishes}

\author{
Jacob B. Hughes ${ }^{1}$, Joseph E. Hightower ${ }^{2}$ \\ ${ }^{1}$ North Carolina State University \\ ${ }^{2}$ U. S. Geological Survey - North Carolina Cooperative Fish and Wildlife Research Unit \\ Presenter: Jacob B. Hughes, (919)513-2469, jbhughe3@ncsu.edu
}

Anadromous fishes are important commercial, recreational, and ecological resources, so reliable population estimates are needed to ensure proper management. Riverine hydroacoustic techniques are a proven and effective method of monitoring upstream migration of anadromous fishes. We used a combination of sidelooking split-beam and side- and down-looking multibeam imaging sonars in a Bayesian framework to assess spawning run size of striped bass Morone saxatilis, American shad Alosa sapidissima, hickory shad $A$.

mediocris, alewife $A$. pseudoharengus, blueback herring $A$. aestivalis, and semi-anadromous white perch $M$. americana, in the Roanoke River, NC during 2010 and 2011. A $430 \mathrm{kHz}$ split-beam transducer was aimed cross-channel to gather count data on upstream-moving fishes in mid-channel and near-bottom zones of the river. The longer range is a major advantage of split-beam sonar (relative to the multibeam sonar) but river bottom unevenness can result in 'blind-spots'. Also, the narrow beam width near the transducer can cause near-shore fish to pass undetected. We used a down-looking multibeam sonar technique to address blindspots in split-beam coverage and monitor cross-channel and vertical distributions. A side-looking multibeam sonar technique monitored near-shore passage. The side-looking multibeam sonar was more effective than 
our split-beam in covering the first $10 \mathrm{~m}$ from the transducer, observing more fish in 2011 than total splitbeam counts in 2010 and 2011combined. Multibeam sonar deployments also provided size and shape information that is useful in partitioning run size estimates by species. A Bayesian framework allows us to conform our analysis to our study design and easily combine data from multiple sources. Our monitoring protocol should be widely applicable for estimating run size of migratory fishes because it can be adapted to rivers of any width or cross-sectional topography.

\title{
WHERE'S THE BEEF? Why 20 Years of Predicted Global Warming Effects on Fish Distributions Remain Unsubstantiated
}

\author{
Daniel J. Isaak ${ }^{1}$, Bruce E. Rieman ${ }^{2}$ \\ ${ }^{1}$ U.S. Forest Service, Rocky Mountain Research Station, Boise Aquatic Sciences Laboratory \\ ${ }^{2}$ Current address: P.O. Box, 1541, Seeley Lake, MT 59868 \\ Presenter: Daniel J. Isaak, (208)373-4385, disaak@fs.fed.us
}

Environmental changes associated with anthropogenic climate change are predicted to substantially degrade global biodiversity during the $21^{\text {st }}$ century. This concern motivated development of numerous bioclimatic models during the last 20 years to forecast potential effects on stream fishes. Despite generally dire forecasts for many species of concern and significant resource commitments to maintaining these species, biological validation of predictions has rarely occurred and the accuracy of forecast declines is unknown. Moreover, validation is difficult because current bioclimatic models yield predictions that are either untestable or so imprecise that definitive answers will not be obtained within timescales useful for many management decisions (e.g., 10 - 20 years). Here, we develop a general framework for making stream-specific predictions of isotherm shift rates (ISRs) based on a key assumption inherent to all bioclimatic models: that a critical temperature isotherm delimits population and species boundaries and that biological distributions will track these isotherms moving to higher elevations or latitudes as the climate warms. Implementing the framework on individual streams requires only stream slope measurements from a GIS and easily collected biological and temperature survey data. Generic ISR curves developed for streams with lapse rates $\left(\sim 0.4^{\circ} \mathrm{C} / 100 \mathrm{~m}\right.$ elevation gain) and long-term warming rates $\left(\sim 0.1-0.2^{\circ} \mathrm{C} /\right.$ decade) observed in the Rocky Mountain region suggest isotherms are currently shifting at $1-10 \mathrm{~km} /$ decade and will move $4-40 \mathrm{~km}$ by the year 2050 . Fish populations and species with greater mobility or large ranges may be able to adjust their distributions and track suitable isotherms if migratory corridors are not blocked, but other fishes will be vulnerable to temperature changes. Headwater populations with $<10 \mathrm{~km}$ of thermally suitable habitat that lack elevational refugia are at greatest risk and could be extirpated by 2050 as warming continues. A power analysis suggests the ability to detect trends in biological distributions will be greatest where ISRs are largest and streams exhibit low inter-annual temperature variance, but even in optimal areas, monitoring for a minimum of 20 years may be required for trend detection. Although initiation of new monitoring efforts will be useful, resurveys of historical fish survey sites should be a priority to determine the rates at which biological distributions are shifting. Documenting these shifts is critical information for developing more accurate climate risk assessments and for providing managers the evidence needed to make difficult decisions regarding where resources are committed to preserve populations. 


\title{
Climate Change Effects on Stream and River Temperatures Across the Northwest U.S. from 1980-2009
}

\author{
Daniel J. Isaak, Sherry Wollrab, Dona Horan and Gwynne Chandler \\ U.S. Forest Service, Rocky Mountain Research Station, Boise Aquatic Sciences Laboratory \\ Presenter: Daniel J. Isaak, (208)373-4385, disaak@fs.fed.us
}

Thermal regimes in rivers and streams are fundamentally important to aquatic ecosystems and are expected to change in response to climate forcing as the Earth's temperature warms. Description and attribution of stream temperature changes are key to understanding how these ecosystems may be affected by climate change, but difficult given the rarity of long-term monitoring data. We assembled 18 temperature time-series from sites on regulated and unregulated streams in the northwest U.S. to describe historical trends from 1980-2009 and assess thermal consistency between these stream categories. Statistically significant temperature trends were detected across seven sites on unregulated streams during all seasons of the year, with a cooling trend apparent during the spring and warming trends during the summer, fall, and winter. The amount of warming more than compensated for spring cooling to cause a net temperature increase, and rates of warming were highest during the summer (raw trend $=0.17^{\circ} \mathrm{C} /$ decade; reconstructed trend $=$ $0.22^{\circ} \mathrm{C} /$ decade). Air temperature was the dominant factor explaining long-term stream temperature trends ( $82-94 \%$ of trends) and inter-annual variability (48-86\% of variability), except during the summer when discharge accounted for approximately half $(52 \%)$ of the inter-annual variation in stream temperatures. Seasonal temperature trends at eleven sites on regulated streams were qualitatively similar to those at unregulated sites if two sites managed to reduce summer and fall temperatures were excluded from the analysis. However, these trends were never statistically significant due to greater variation among sites that resulted from local water management policies and effects of upstream reservoirs. Despite serious deficiencies in the stream temperature monitoring record, our results suggest many streams in the northwest U.S. are exhibiting a regionally coherent response to climate forcing. More extensive monitoring efforts are needed as are techniques for short-term sensitivity analysis and reconstructing historical temperature trends so that spatial and temporal patterns of warming can be better understood. Efforts are also needed to develop a comprehensive regional stream temperature database and temperature model that could facilitate more precise climate vulnerability assessments and prioritization strategies. Such strategies will be needed as continued temperature increases this century place increasing stress on important regional salmon and trout populations and make efforts to conserve these species more difficult.

\section{Migration and Physiology of Clearwater River Steelhead Kelts}

\author{
Bryan Jones ${ }^{1}$, Christine M. Moffitt ${ }^{2}$, Tim Copeland ${ }^{3}$, Brett Bowersox ${ }^{3}$, Doug Hatch ${ }^{4}$, Zach Penney ${ }^{1}$ and Jessica \\ Buelow $^{1}$ \\ ${ }^{1}$ Department of Fish and Wildlife Resources University of Idaho \\ ${ }^{2}$ US Geological Survey, Idaho Cooperative Fish and Wildlife Research Unit \\ ${ }^{3}$ Idaho Department of Fish and Game \\ ${ }^{4}$ Columbia River Inter Tribal Fish Commission \\ Presenter: Bryan Jones, (208)816-0065, jone6267@vandals.uidaho.edu
}

We are studying the fate of natural origin steelhead kelts from three Clearwater River tributaries in an effort to understand why few fish are iteroparous. Fish Creek, a tributary of the Lochsa River, supports a natural population of B-run steelhead; the Potlatch River supports a mix of both A and B-run naturally spawning steelhead and several documented repeat spawning (iteroparous) fish; and Crooked River, a tributary of the South Fork Clearwater River, supports a population of B-run steelhead that was restored following the removal of the Harpster Dam in 1962. No iteroparous steelhead have been documented previously in Fish Creek or Crooked River. From 2009 to 2011 we partnered with Idaho Fish and Game biologists and nonlethally sampled blood from steelhead kelts at tributary weirs in addition to determining sex, fork length, 
external body condition, and PIT-tagging each fish. Biochemical attributes of plasma samples were correlated with external body condition with the highest nutritional metrics in good condition fish. We found consistent trends in blood plasma metrics between tributaries as well as between years. In 2011, 43 kelts in good physical condition from the Potlatch River and Fish Creek were selected and surgically implanted with acoustic transmitters to allow us to follow survival and rate of migration downstream to Lower Granite Dam. Kelts released from Fish Creek slowed migration as they reached Lower Granite Reservoir; and kelts that migrated later in the season traveled faster than did earlier migrating kelts. Kelts from the Potlatch River had a slower migration rate. We detected $88 \%$ of the tagged kelts approaching Lower Granite Dam, however only 4 (9\%; including 3 from Fish Creek) were detected in the lower Columbia River below Bonneville Dam.

\title{
A Watershed Scale Test of Optimal Foraging in a Variable Environment
}

\author{
Brian Kennedy and Rick Hartson \\ Departments of Fish and Wildlife Sciences and Biological Sciences, University of Idaho \\ Presenter: Brian Kennedy, (208)885-5171, kennedy@uidaho.edu
}

Theory in ecology can guide our interpretation of the patterns that we see in nature and can provide a framework by which to make predictions. Our intuition can lead us to interpret unequal distributions in the density of organisms across space as a representation of differences in habitat quality in which high densities generally relate to higher quality habitat. However, one prediction from optimal foraging theory suggests that mobile organisms will distribute themselves in space based upon their perceptions of the distributions of resources, thereby standardizing their performance to a mean across a relevant scale of the environment. Our overarching goal is to test the hypothesis that organisms (juvenile steelhead, Oncorhynchus mykiss) distribute themselves based upon the availability of resources. We employ an optimal foraging framework to interpret the results of a watershed scale movement experiment in a system in which juvenile salmonids are free to move amongst patches in response to differences in habitat quality and food abundance. We test the null hypothesis that performance metrics - growth and survival - are equitably distributed at the watershed scale and that when the differences among patches at the local scale are most extreme, that changes in immigration and emigration rates are most likely to occur. Lastly, we quantify how changes throughout the growing season, as well as differences across years, influence these performance-based movement patterns. Our results suggest that movements among patches are more likely to be dispersive and that active immigration into sites of high quality may be rare. Furthermore, our results suggest that tradeoffs among performance metrics may complicate conclusions about spatial variation in habitat quality, which has implications for how we interpret the outcomes of our management, conservation and restoration strategies.

\section{Nutrient Flux by Chinook Salmon in Idaho streams: The Ins and Outs, and Implications for Management}

\author{
Andre E. Kohler ${ }^{1}$, Timothy Copeland ${ }^{2}$, David A. Venditti ${ }^{2}$, Mark S. Wipfli ${ }^{3}$, Paul Kusnierz ${ }^{1}$, Josh Gable ${ }^{1}$, Lytle \\ Denny ${ }^{1}$, Bert Lewis ${ }^{4}$ and Bruce Barnett ${ }^{2}$ \\ ${ }^{1}$ Shoshone-Bannock Tribes \\ ${ }^{2}$ Idaho Department of Fish and Game \\ ${ }^{3}$ University of Alaska Fairbanks \\ ${ }^{4}$ Alaska Department of Fish and Game \\ Presenter: Andre E. Kohler, (208)239-4566, akohler@sbtribes.com
}

Anadromous salmonids are important vectors of energy and nutrients across many landscapes. Semelparous fishes drive nutrient fluxes across habitat boundaries and can influence community and food web structure in aquatic and terrestrial ecosystems. The transport of marine-derived nutrients to freshwater habitats by adult 
Chinook salmon (Oncorhynchus tshawytscha) can fuel production across multiple trophic levels, with specific implications for freshwater productivity and the growth and survival of ESA listed fishes. In Idaho, where 25$50 \%$ of streams are proposed to be nutrient-limited, naturally spawning spring Chinook salmon represent an important resource subsidy and linkage between marine and land-based ecosystems. However, this flow of energy and nutrients is not uni-directional (i.e., upstream only); in addition to passive nutrient export via stream flow, smolt migrants actively export nutrients from natal freshwater rearing habitats. And in some cases, this nutrient export by smolts can exceed import by adults, with a profound influence on organic matter and nutrient budgets in freshwater ecosystems. We evaluated the nutrient flux to and from streams across central Idaho using Chinook salmon adult escapement and brood year parr, presmolt, and smolt migrant data from 1998 to 2008. This information will help scientists and natural resource managers understand nutrient flux across the landscape, and potential limiting factors affecting freshwater productivity and ESA listed populations.

\title{
How Big is Lake Lowell's Common Carp Problem?
}

\author{
Joe Kozfkay, Jeff Dillon and Art Butts \\ Idaho Department of Fish and Game \\ Presenter: Joe Kozfkay, (208)465-8465 ext. 310, joe.kozfkay@idfg.idaho.gov
}

Lake Lowell is a 3,640 ha off-channel, storage reservoir that is filled by diverted Boise River water. The reservoir is bounded by the Deer Flat National Wildlife Refuge and offers a variety of wildlife-based recreational opportunities close to Idaho's population center. The reservoir supports popular fisheries for black basses, but other fisheries, especially for panfish, have decreased after a series of low water years that occurred during the early 1990s. Recent surveys have indicated that the fish community in Lake Lowell has shifted to a rough-fish dominated state, composed primarily of common carp Cyprinus carpio and largescale sucker Catostomus macrocheilus. This shift has negatively affected sportfish populations, water quality, and aquatic habitats. During 2010, we initiated efforts to gain a better understanding of the common carp population with the intention of determining effective control options. A mark-recapture estimate indicated that the reservoir contained 1.2 million or about 2.2 million $\mathrm{kg}$ of common carp. These density estimates place Lake Lowell's carp population at the high end of the spectrum compared to other waters. Assessment of ages, age-frequency, and a catch curve indicate that carp in Lake Lowell are relatively young, exhibit frequent successful reproduction (annual), and have high natural mortality rates. These characteristics are unlike most other well studied common carp populations. Because of the morphology of Lake Lowell and total biomass of this population, effective control may be difficult and expensive unless creative control options can be developed.

\section{Enhanced Protection of a Bacterial Coldwater Disease Vaccine by Culturing in Iron Limited Media}

\author{
Amy Long ${ }^{1}$, Tyson R. Fehringer ${ }^{1}$, Marissa A. Swain ${ }^{2}$, Benjamin R. LaFrentz ${ }^{3}$, Douglas R. Call ${ }^{4}$ and Kenneth D. \\ Cain $^{1}$ \\ ${ }^{1}$ Department of Fish \& Wildlife Resources, University of Idaho \\ ${ }^{2}$ Department of Marine Science, Eckerd College \\ ${ }^{3}$ Aquatic Animal Health Research Unit, U. S. Department of Agriculture, Agricultural Research Service \\ ${ }^{4}$ Department of Veterinary Microbiology and Pathology, Washington State University, \\ Presenter: Amy Long, (208)885-5018, long8524@vandals.uidaho.edu
}

A live attenuated vaccine effective against Flavobacterium psychrophilum, the causative agent of Bacterial Coldwater Disease (BCWD), has been developed and is being evaluated for widespread use. The vaccine was derived from F. psychrophilum strain CSF 259-93, originally isolated from diseased rainbow trout 
(Oncorhynchus mykiss). However, high mortality in other salmonid species, specifically Coho salmon (O. kisutch), due to BCWD is common. In the current study, we evaluated the efficacy of the vaccine in Coho salmon. Additionally, we sought to increase the immunogenicity of the live attenuated strain by altering the iron concentration of the bacterial growth media as studies have shown that antigenic protein expression is increased when pathogenic bacteria are grown in iron-limited media (ILM). Fish were vaccinated by either immersion or injection with the live attenuated strain grown in regular media or ILM, and a booster dose was administered at 4 weeks. Serum was collected at 4 and 6 weeks post-vaccination. Six weeks after initial vaccination, fish were challenged with the virulent $F$. psychrophilum strain and mortalities monitored for 28 days. Antibody titers were not significantly different between the two media types and the two delivery methods. However, the relative percent survival was higher in both the ILM injection and immersion groups (98\% and 69\%) as compared to the regular media (90\% and $37 \%)$. Ongoing studies are investigating the use of ILM to increase the pathogenicity of the virulent strain to aid in the development of a disease challenge model that mimics natural exposure to F. psychrophilum. In summary, the live attenuated vaccine is effective in protecting other salmonid species against BCWD, and immunogenicity can be increased by altering growth media.

\title{
Update on the Status of Pygmy Whitefish in Idaho
}

\author{
Melo A. Maiolie and Jim Fredericks \\ Idaho Department of Fish and Game \\ Presenter: Melo A. Maiolie, (208)769-1414, melo.maiolie@idfg.idaho.gov
}

Pygmy whitefish Prosopium coulteri are found in only four water bodies in Idaho; Upper Priest Lake, Priest Lake, Spirit Lake and Lake Pend Oreille. They are listed as a "species of greatest conservation need" in Idaho and categorized as a species "lacking essential information pertaining to status." From 2009 to 2011 we conducted hydroacoustic surveys and bottom trawling on three of these lakes to estimate the abundance of pygmy whitefish and collect some basic information on their populations. We estimated Upper Priest Lake contained about 150,000 pygmy whitefish based on hydroacoustic density estimates and the findings that $95 \%$ of the fish caught in deep water bottom trawls were pygmy whitefish. Netted pygmy whitefish ranged from $69 \mathrm{~mm}$ to $147 \mathrm{~mm}$ in total length and were 2 to 6 years old. Spirit Lake contained an estimated 43,000 fish based on the catch of a bottom trawl. Pygmy whitefish ranged from 104 to $199 \mathrm{~mm}$ in total length in Spirit Lake with ages from 2 to 6 years old. Priest Lake was not suitable for making population estimates with our methodologies, but a few pygmy whitefish were caught in each bottom trawl in one section of the lake. Numerous small fish were seen in the hydroacoustic surveys, but they could not be netted since they were in deep water and off of the lake's bottom. Lake Pend Oreille was not surveyed to determine pygmy whitefish densities. However, pygmy whitefish were occasionally caught in mid-water trawl sampling for kokanee. Also, two pygmy whitefish were gillnetted at depths $>300 \mathrm{~m}$ indicating the species had colonized the deepest regions of the lake. Our investigations reveal that pygmy whitefish have strong populations in Upper Priest and Spirit lakes, and are at least present to a wide extent in Priest Lake and Lake Pend Oreille.

\section{Balancing Chinook Salmon and Kokanee in Coeur d'Alene Lake, Idaho}

\author{
Melo A. Maiolie and Jim Fredericks \\ Idaho Department of Fish and Game \\ Presenter: Melo A. Maiolie, (208)769-1414, melo.maiolie@idfg.idaho.gov
}

For nearly three decades, Coeur d'Alene Lake, Idaho, has provided important fisheries for both kokanee Oncorhynchus nerka and Chinook salmon $O$. tshawytscha. These two fisheries have made the lake one of the most valued fisheries in the State with an estimated worth of $\$ 6.7$ million in 2003 . The balance between the 
two species has been dynamic with both species going through wide cycles in abundance as managers regulated Chinook salmon stocking to match the kokanee population. Prior to stocking Chinook salmon in 1982, kokanee harvest was estimated at about 500,000 kokanee annually, with the lake providing about 250,000 angler hours/year. Kokanee size was declining with adults reaching about $250 \mathrm{~mm}$ in total length. Chinook salmon were introduced in 1982 mainly to reduce kokanee densities and increase their size. Fishing effort remained fairly constant for the next 14 years after the introduction of Chinook salmon. Chinook salmon contributed 2,200 to 3,300 fish to the harvest with an added trophy component. However, high water in 1996 and 1997 caused a decline in kokanee abundance, and an imbalance in the predator/prey relationship. Kokanee abundance remained low for the next 12 years, impacting the kokanee fishery. Total fishing effort declined to $95,000 \mathrm{~h} /$ year, with a kokanee harvest of only 17,000 fish. To rebalance predator and prey, managers reduced the numbers of Chinook salmon stocked, limited the number of wild-spawn Chinook salmon redds, closed the fall fishery for kokanee to protect spawning adults, and reduced the harvest limit on kokanee. Kokanee numbers rebounded, but quickly exceeded target densities with an associated decline in kokanee size. Although the current fishery achieves management objectives, a retrospective look at thirty years of management history demonstrates the difficulty in consistently maintaining a balance between these two populations.

\title{
Brook Trout Diet Patterns During Summer Oxygen Depletion in Owhi Lake Using Stable Isotope Analysis and Lipid Extraction
}

\author{
Amy A. Martin ${ }^{1}$, Barry C. Moore ${ }^{1}$ and Ed Shallenberger ${ }^{2}$ \\ ${ }^{1}$ Washington State University \\ ${ }^{2}$ Colville Confederated Tribes
}

Presenter: Amy A. Martin, (509)335-8560, amy.martin@email.wsu.edu

Owhi Lake is a dimictic lake located in north central Washington on the Colville Confederated Tribes' reservation. Owhi provides recreational opportunities for tribal members and serves as the hatchery brood stock source for eastern brook trout (Salvelinus fontinalis). However, these resources are threatened by recent severe cyanobacteria blooms and low dissolved oxygen in the summer hypolimnion.

Indications are that mortality rates in Owhi fish are high. In response to concerns about water quality and fish health in Owhi, we are conducting a study of summer habitat conditions using stable isotope analysis (SIA) to assess how low hypolimnetic DO and high epilimnetic temperatures may influence fish diets.

We are using isotopic signatures from both muscle and liver fish tissues to determine long term vs. short term dietary trends. Samples will also be evaluated for the influence of lipid removal, a non-standard processing method that reduces sample variability. Stomach content analysis is used to support SIA findings. Preliminary evaluation of prey importance by SIA diverged from previous gut content analyses. SIA has developed into an important tool with a wide range of ecological applications; lipid removal could improve interpretation of trophic relationships in aquatic systems by reducing variability within and among species. 


\title{
The Origin and Distribution of Kelt Steelhead Trout in the Snake River, ID: Genetic Stock ID at Lower Granite Dam
}

\author{
Andrew Matala ${ }^{1}$, Christine Moffitt ${ }^{2}$, Jessica Buelow ${ }^{3}$, Zachary L. Penney ${ }^{3}$, Doug Hatch ${ }^{4}$ and Shawn R. Narum ${ }^{1}$ \\ ${ }^{1}$ Columbia River Inter-Tribal Fish Commission \\ ${ }^{2}$ US Geological Survey, Idaho Cooperative Fish and Wildlife Research Unit \\ ${ }^{3}$ College of Natural Resources Department of Fish and Wildlife \\ ${ }^{4}$ CRITFC, 729 N. E. Oregon, Suite 200, Portland OR. 97232 \\ Presenter: Andrew Matala, (208)837-9096, mata@critfc.org
}

The iteroparous life history potential of steelhead trout is characterized by post-spawn survival, secondary or repeat migrations, and the opportunity for some individuals to spawn across multiple years. Despite the presumed increase in lifetime fecundity of iteroparous individuals, population-specific rates of iteroparity are variable, and are likely to impart local differences in productivity, genetic diversity and demographic stability. The distinct B-run steelhead are typically larger than A-run fish, owing to greater ocean residence time (two vs. one year, respectively). Iteroparity has been shown to be negatively correlated with size, where greater proportions of kelts (post-spawn) are observed among populations of A-run steelhead. In our evaluation we used a suite of 192 single nucleotide polymorphism (SNP) loci, and genetic stock identification (GSI) to examine the origins of kelt steelhead in the Snake River Basin. Initially we resolved genetic distinctions among contributing stocks that comprised our genotypic reference or baseline. The baseline was delineated into ten reporting units on the basis of genetic similarity among populations, including three units in the Clearwater River, four in the Salmon River, a Grande Ronde unit, an Imnaha unit, and a lower Snake River unit. A mixed stock kelt collection of unknown origin $(n=1500)$ was sampled during downstream migration at Lower Granite Dam (LGD) in 2010. Kelt origins were determined by proportional assignment among baseline reporting groups using likelihood tests in a GSI approach. Results of our evaluation are being used to better understand the spatial and temporal distributions of post-spawn kelts (inferring a potential iteroparous life history) throughout the region, as well as the relative association of iteroparity to biological or demographic attributes including size, sex ratios and run timing.

\section{Influence of Barriers to Movement on the Population Genetic Structure of Westslope Cutthroat Trout}

\author{
Sammy L. Matsaw Jr., Janet L. Loxterman and Ernest R. Keeley \\ Idaho State University \\ Presenter: Sammy L. Matsaw Jr., (208)530-2019, matssamm@isu.edu
}

Although historic isolation of fish populations can occur as a result of natural geologic events such as land uplifting leading to canyons, mountains, and islands; more recent human activities (roads, dams, urban and agricultural expansion) are rapidly fragmenting native fish populations. When barriers to movement in aquatic ecosystems impede gene flow or connectivity between fish populations this can lead to changes in gene frequencies between populations. In this study, we assess genetic differentiation and diversity of westslope cutthroat trout (Oncorhynchus clarkii lewisi) populations to examine the effects of isolation and habitat fragmentation isolated by natural and artificial barriers to movement. We compare measures of genetic differentiation between inter-connected populations with those isolated above movement barriers. Our comparisons include barriers created by naturally occurring waterfalls and by more recent humancreated barriers to movement. Our study was conducted in the Salmon River Basin of central Idaho to compare whether any patterns of geographic isolation occur over a significant range of this species distribution within the traditional-use area of the Shoshone-Bannock Tribes. Currently, we are genotyping individual fish and our results should be mostly complete to verify effects of natural and artificial barriers on the genetic population structure of cutthroat trout. Our data will determine if geographic isolation between populations of cutthroat trout leads to significantly higher levels of genetic differentiation and lower levels of 
diversity when isolated above movements barriers are from recent occurrence of isolation and whether such isolation differs from historic, naturally occurring isolation patterns. Any differences may have important management implications for the conservation of westslope cutthroat trout populations in the Salmon River Basin.

\title{
Effect of Creel Survey Design and Catch Rate Estimation on Total Catch Estimates in Chinook Salmon Fisheries in Idaho
}

\author{
Joshua L. McCormick ${ }^{1}$, Michael C. Quist ${ }^{2}$ and Daniel J. Schill ${ }^{3}$ \\ ${ }^{1}$ University of Idaho \\ ${ }^{2}$ USGS, Idaho Cooperative Fish and Wildlife Research Unit, University of Idaho \\ ${ }^{3}$ Idaho Department of Fish and Game \\ Presenter: Joshua L. McCormick, (724)840-2325, mcco7627@vandals.uidaho.edu
}

As a result of declining Chinook salmon Oncorhynchus tshawytscha populations in the Columbia River basin, hatchery production has been adopted to supplement wild stocks and provide sport, commercial, and ceremonial tribal fisheries. The number of allowable hatchery Chinook salmon that can harvested by sport anglers in Idaho is regulated by the U.S. v. Oregon Management Agreement which determines harvest shares for sport and tribal fisheries. Fisheries must be closed once the harvest share of hatchery fish has been met. Creel surveys are the primary technique used to obtain information on harvest in Chinook salmon sport fisheries in Idaho. Roving creel surveys are typically conducted in fisheries that have diffuse access, whereas access surveys are conducted in fisheries that have few access points. Both creel surveys use an estimate of angling effort (i.e., based on angler counts) that is expanded over the hours in the fishing day to estimate total angler hours. Estimates of angling effort are then combined with catch rates that are obtained from angler interviews to provide an estimate of total catch. Once interviews are conducted using access or roving survey designs, mean catch rate can be estimated using the ratio-of-means (ROM) estimator or mean-ofratios (MOR) estimator. Using different survey designs (i.e., access, roving surveys) and different catch rate estimators (i.e., ROM, MOR) frequently result in different estimates of total catch in the same fishery. Therefore, the objective of this study was to examine the relative bias and precision of total catch estimates in Chinook salmon fisheries in Idaho using access and roving survey designs, and ROM and MOR catch rate estimators.

\section{Effects of Body Mass, Water Temperature, and Consumption Rates on Juvenile Steelhead (Oncorhynchus mykiss) Growth in a Hydrologically Altered Watershed}

\author{
Knut Marius Myrvold and Dr. Brian P. Kennedy \\ University of Idaho \\ Presenter: Knut Marius Myrvold, (208)310-2550, kmyrvold@uidaho.edu
}

As increasing urbanization and changing climates contribute to altered hydrologic regimes, there is increasing need to understand how stream water supply and temperature influences the energy requirements for growth of fishes. In hot and dry summer climates the streamwater temperature can exceed the scope of growth for cool- and coldwater species such as steelhead (Oncorhynchus mykiss). Water storage reservoirs and reduced streamflow can further elevate streamwater temperatures and reduce prey delivery rates, hence exacerbating the temperature effects on growth, but such factors often act in complex ways. We employed a spatially explicit bioenergetic modeling approach calibrated for juvenile steelhead to 1) assess the spatial and temporal distribution of energetically favorable habitat, 2) relate achieved growth in individually tagged fish to their consumption rates and the thermal environment, and 3) relate these patterns to hydrologic alterations in the Lapwai watershed of north-central Idaho, USA. We found that the thermal 
regimes exerted considerable constraints on the growth opportunities in juvenile steelhead. 2010 was a high water year, and the storage reservoirs and minimum flow requirements in streams affected by water withdrawals resulted in lower, closer to optimal, temperatures compared to streams with natural hydrographs (range 2.6 to $7.4{ }^{\circ} \mathrm{C}$ lower). Fish allocated considerable amounts of their consumed energy towards maintenance metabolism when temperatures were high, resulting in suppressed growth rates. Under similar stream temperatures, growth rates were negatively associated with size $\left(R^{2}=0.47\right)$ in subyearling steelhead. However, growth rates were weakly positively related to fish mass when considering all sites and accounting for differences in water temperature (and hence metabolic expenses). These differences can be attributed to differences in food availability among sites. Due to the positive relationship between temperature and metabolic demands, consumption rates increased with fish size $\left(R^{2}=0.33\right)$ but this did not result in proportionally higher growth rates $\left(R^{2}=0.10\right)$. Finally we found that fish in impacted streams allocated a higher fraction of consumed energy to growth than did fish in unimpacted streams, marginally for subyearling and substantially for yearling steelhead.

\title{
Thermal Acclimation and Adaptation in Redband Trout from Desert and Montane Populations
}

\author{
Shawn R. Narum ${ }^{1}$, Nathan R. Campbell ${ }^{1}$, Kevin Meyer ${ }^{2}$, Mike R. Miller ${ }^{3}$ and Ron Hardy ${ }^{4}$ \\ ${ }^{1}$ Columbia River Inter-Tribal Fish Commission \\ ${ }^{2}$ Idaho Department of Fish \& Game \\ ${ }^{3}$ Institute of Molecular Biology, HHMI \\ ${ }^{4}$ University of Idaho
}

Presenter: Shawn R. Narum, (208)837-9096 ext. 1120, nars@critfc.org

To elucidate the mechanisms of thermal acclimation and adaptation in desert populations of redband trout (Oncorhynchus mykiss gairdneri), we tested hypotheses related to the heat shock response and identified genomic regions associated with survival to elevated temperatures over a six week thermal stress experiment within and among strains from warm and cool environments, plus their F1 crosses. An adaptive heat shock response was observed as the expression of heat shock genes in fish from the desert population of Little Jacks $\mathrm{Cr}$. was more similar to control (unstressed) fish and significantly different $(p \leq 0.05)$ from those from the montane population of Keithley $\mathrm{Cr}$., while F1 crosses were intermediate. High induction of Hsps in the montane strain appeared to improve short term survival during first exposure to high temperatures, but high physiological costs of Hsp production may have led to poorer long term survival. In contrast, the desert strain had significantly lower heat shock response than the montane fish and F1 crosses, suggesting that these desert fish have evolved alternative mechanisms to deal with thermal stress that provide better balance of physiological costs. Genome wide tests of 12,200 SNPs found significant association of multiple genomic regions with survival under thermal stress, and these polymorphisms may be utilized to screen broadly across the species range to help predict the potential for adaptation under various scenarios of climate change. These results demonstrate how aquatic species may evolve adaptive responses to thermal stress and provide insight for understanding how climate change may impact ectotherms.

\section{A Comparison of the Nutritional and Energetic Status of Kelts from the Snake River and Coastal Situk River, AK Using Blood Plasma Metrics}

\author{
Zachary L. Penney ${ }^{1}$, Christine Moffitt ${ }^{2}$, Jessica Buelow ${ }^{1}$, Bryan Jones ${ }^{1}$ and Brian Marston ${ }^{3}$ \\ ${ }^{1}$ University of Idaho, Department of Fish and Wildlife Resources \\ ${ }^{2}$ US Geologic Survey, Idaho Cooperative Fish and Wildlife Research Unit \\ ${ }^{3}$ Alaska Department of Fish and Game \\ Presenter: Zachary L. Penney, (208)885-7139, penn4282@vandals.uidaho.edu
}


Steelhead trout iteroparity (repeat spawning) is highly variable throughout the northeastern Pacific, ranging from less than $1 \%$ in inland populations to as high as $70 \%$ in coastal populations. In general, it has been observed via scale analysis that coastal steelhead exhibit higher rates of iteroparity than inland populations. The physiological capacity for iteroparity between inland and coastal steelhead is not well understood, but has been attributed to differences in gonadal maturation strategies, freshwater re-entry timing, migration distance, and total time spent in freshwater. We provide a physiological assessment of nutritional factors between inland and coastal steelhead kelts using measures of blood plasma. From 2009 to 2011, steelhead from the Snake River subbasin were sampled at the Lower Granite Dam juvenile bypass facility $(\mathrm{N}=1649)$ and multiple weir sites in tributaries of the Clearwater River ( $N=272$ ). For comparison, blood plasma was collected from kelts in the Situk River ( $N=37$ ), a coastal system in southeast Alaska in 2011. Plasma nutritional factors of cholesterol and triglycerides were nearly three times higher in Situk River kelts than in Snake River kelts. When detectable, values of plasma protein were similar between Situk and Snake River kelts; however, plasma protein was below detection limits in 52\% of Snake River kelts and in only 32\% of Situk River kelts. Our results suggest that coastal Situk River kelts have greater nutritional and energetic reserves following spawning than inland steelhead kelts from the Snake River subbasin. We speculate that differences in energy reserves of inland and coastal steelhead contribute to their potential for repeat-spawning.

\title{
Thermal Shift in Maximum Consumption Helps Explain Bioenergetics and Growth by Subyearling Fall Chinook Salmon
}

\author{
John M. Plumb ${ }^{1}$, Christine M. Moffitt ${ }^{2}$, Jeffrey A. Yanke ${ }^{3}$, William P. Connor ${ }^{4}$ and Kenneth F. Tiffan ${ }^{5}$ \\ ${ }^{1}$ University of Idaho \\ ${ }^{2}$ U.S. Geological Survey, Idaho Cooperative Fish and Wildlife Research Unit, \\ ${ }^{3}$ Oregon Department of Fish and Wildlife \\ ${ }^{4}$ U.S. Fish and Wildlife Service, Idaho Fisheries Resource Office \\ ${ }^{5}$ U.S. Geological Survey, Columbia River Research Laboratory \\ Presenter: John M. Plumb, (509)538-2299 ext. 203, jplumb@usgs.gov
}

We used published and unpublished data from controlled laboratory trials of three stocks of ocean-type fall Chinook salmon Oncorhynchus tshawytsha from the Pacific Northwest to evaluate the performance of Wisconsin based bioenergetics models in accurately predicting fish growth across a range of temperatures. Model data were from studies of subyearling fall Chinook salmon from the Snake/Columbia River, the Nechako/Fraser River, and the Big Qualicum River. Fish from these stocks of Chinook salmon ranged from 1.5 $-7.2 \mathrm{~g}$ at the beginning of trials, and temperatures ranged from $14-26^{\circ} \mathrm{C}$. We found maximum consumption and growth in laboratory studies was achieved at higher temperatures than would be expected by using parameters in the existing bioenergetic model. We adjusted four parameters: the lower limit; optimum, maximum, and upper thermal limit to better define thermal-consumption relationships for subyearling Chinook salmon. To test our adjustments, the food consumed by fish in the laboratory trials was used to simulate the expected growth using the Wisconsin model with and without adjustment of thermalconsumption parameters. The adjusted parameters improved the mean square error between observed and predicted fish weights by $31 \%$, and thus, we conclude the adjusted thermal-consumption values may produce better estimates of consumption and growth for subyearling ocean-type fall Chinook salmon. 


\title{
Age Structure and Growth Analysis of Bowfin in Lake Lindsay Grace, Ga.
}

\author{
Nick Porter ${ }^{1}$, Michael C. Quist ${ }^{2}$, Timothy Bonvechio ${ }^{3}$ and Joshua L. McCormick ${ }^{4}$ \\ ${ }^{1}$ Department of Fish and Wildlife Resources, University of Idaho \\ ${ }^{2}$ US Geological Survey, Idaho Cooperative Fish and Wildlife Research Unit, University of Idaho \\ ${ }^{3}$ Georgia Department of Natural Resources \\ ${ }^{4}$ Idaho Cooperative Fish and Wildlife Research Unit, University of Idaho \\ Presenter: Nick Porter, (208)582-1945, port5518@vandals.uidaho.edu
}

Bowfin Amia calva are the only extant species in the family Amiidae. Due to their trophic position as an apex predator, bowfin contribute greatly to ecosystem stability and function. Traditionally, many sport anglers considered the bowfin an undesirable species that competes with more desirable sport or commercial species. However, some anglers hold bowfin in high regard for their fighting ability when caught in sport fisheries. Bowfin have also recently become an important source of roe for the caviar market. Despite the wide distribution of bowfin and their importance in aquatic systems, few studies have been conducted on their population dynamics. Most research has focused on food habits and potential effects on other fish assemblages, or on their unique spawning ecology. Objectives of this study were to describe the age structure (including estimates of recruitment and mortality), sex ratios, and growth of a dense population bowfin in a southern Georgia lake. Age and growth analysis was conducted using fin rays from a representative sample of 90 bowfin from Lake Lindsay Grace, Georgia. Due to the lack of research related to bowfin demographics, results of the study will be used to provide insight on the management of systems containing dense bowfin populations.

\section{Nonlinear Interactions Between Native and Nonnative Fishes: Implications for Management and Conservation}

\author{
Michael C. Quist \\ U. S. Geological Survey, Idaho Cooperative Fish and Wildlife Research Unit, Department of Fish and Wildlife \\ Resources, University of Idaho \\ Presenter: Michael C. Quist, (208)885-4064, mcquist@uidaho.edu
}

Managing nonnative species within the context of native fish conservation remains an important goal of natural resource agencies and fisheries scientists. A key element in developing effective and efficient management strategies is to understand how species interact. If interactions are linear, or nearly so, actions aimed at mitigating or removing the effects of nonnative species may be clearly-defined, predictable, and highly effective. In many systems across North America, however, the relationship between native and nonnative species is nonlinear and likely functions as an ecological threshold. Nonlinear interactions pose an interesting series of challenges to managers; manipulating nonnative fish populations not only requires substantial effort, but responses are often nonlinear and highly unpredictable. The purpose of this presentation is to describe various examples of nonlinear interactions from aquatic systems in the western and midwestern United States, explore whether ecological thresholds provide a general conceptual model for native-nonnative species interactions, and provide insight relevant for management and conservation of native species. 


\title{
Comparisons of Adult Demographics for a Supplemented Summer Chinook Population: A Companion to Parentage Assignment
}

\author{
Craig D. Rabe \\ Nez Perce Tribe DFRM \\ Presenter: Craig D. Rabe, (208)634-5290, craigr@nezperce.org
}

Microsatellite-based parentage assignment and exclusion analysis represent a means by which to detect kinship and parentage within a population, however results should be considered in context with the relative demographic characteristics of the population. To complement results obtained from pedigree analyses, we conducted within-population comparisons of life history characteristics of Johnson Creek supplementation and natural-origin summer Chinook adults. We found that the age at which natural origin Chinook return to Johnson Creek differed significantly from age at return of supplementation origin Chinook, however the assumed heritability of jacking was not apparent when comparing age at return of natural origin Chinook between pre- and post-supplementation periods. We conducted fork length comparisons between natural and supplementation origin Chinook females to provide an index of productivity potential and found natural origin Chinook to be significantly larger (assumedly more fecund) than their supplementation origin counterparts; however the mean size of natural origin females has significantly decreased between pre and post supplementation periods. Supplementation origin Chinook females select similar spawning areas as natural origin females, and do not show fidelity to their release location. Recruit per spawner comparisons (a.k.a. parent to progeny ratios) differed significantly, favoring supplementation origin adults.

\section{How Do Stream Food Webs Respond to the Addition of Salmon Carcass Analogs in Idaho Streams?}

\author{
David P. Richardson ${ }^{1}$, Andre E. Kohler ${ }^{1}$, Amy M. Marcarelli ${ }^{2}$, Jonathan Ebel ${ }^{2}$, Steven Campbell ${ }^{3}$ and Ernest R. \\ Keeley ${ }^{3}$ \\ ${ }^{1}$ Shoshone-Bannock Tribes \\ ${ }^{2}$ Michigan Technological University \\ ${ }^{3}$ Idaho State University \\ Presenter: David P. Richardson, (208)251-3247, drichardson@sbtribes.com
}

In the Columbia River Basin, declining returns of salmon are associated with reduced marine-derived nutrient (MDN) subsidies. Historically, these subsidies contributed an ecologically significant amount of nutrients to freshwater ecosystems and likely fueled ecosystem productivity. We are investigating the effects of pasteurized salmon carcass analog (SCA) additions on freshwater productivity and food web response in nutrient-limited streams of the Salmon River Basin, central Idaho. Our study evaluates response variables that include: streamwater nutrient concentrations; biofilm nutrient limitation; stream metabolism; leaf litter decomposition; biofilm standing crop; macroinvertebrate density, biomass, and drift; periphyton, macroinvertebrate, and salmonid C \& N stable isotope signatures; and salmonid bioenergetics modeling. Results from nutrient diffusing substrata experiments and dissolved nutrient Redfield ratios indicate that biofilms in our study streams are primarily $\mathrm{N}$-limited, with some $\mathrm{N}$ and $\mathrm{P}$ co-limitation. Following SCA treatment, biofilm nutrient limitation did not appear to change and Redfield ratios continued to indicate $\mathrm{N}$ limitation. Correspondingly, streamwater nutrient concentrations and biofilm biomass appeared largely unaffected by SCA treatment. Leaf litter decomposition rates were also unchanged by the addition of SCA. Interestingly, we found a significant increase in benthic macroinvertebrate biomass and density, as well as a short-term increase in macroinvertebrate drift density following SCA additions. These data suggest that the addition of SCA to our study streams increased the abundance and biomass of macroinvertbrates while 
potentially having little effect on biofilm accrual. The lack of a strong basal response (i.e., in biofilm) may be partially explained by top-down grazing effects from macroinvertebrates. Alternatively, limiting factors other than nutrients and macroinvertebrates are controlling biofilm and the strong macroinvertebrate response is the result of a direct feeding pathway provided by SCA addition. Ongoing research will attempt to explain the varied trophic level responses seen during the initial period of this study.

\title{
Greeting the Elephant in the Room: Our Complex Relationship with Nonnative Sport Fishes
}

\author{
Beth L. Sanderson, Michael P. Carey and Katie A. Barnas \\ NOAA Fisheries, Northwest Fisheries Science Center \\ Presenter: Beth L. Sanderson, beth.sanderson@noaa.gov
}

The introduction and establishment of nonnative fishes has contributed to the decline of native species worldwide. Many of the nonnative fish species in the western half of the United States were introduced to provide recreational fishing opportunities. Now widely distributed, these established nonnative sport fish populations may impede the conservation and recovery of native species. As the recreational fishing industry generates billions of dollars of revenue each year, federal and state agencies are caught between a rock and a hard place - they must jointly manage nonnative sport fishes that may in fact contribute to the decline of threatened and endangered species they also oversee. In the Pacific Northwest (PNW), there are more than 80 species of nonnative fishes, including a large number of popular recreational species. Many of the nonnative sport fishes are widely distributed. This is in part due to historical stocking practices which, over the past 40 years, have stocked at least 25 species of non-indigenous fish into WA, OR, and ID. Once established, the impacts of sport fishes can vary widely and complicate management decisions. For example, predation estimates of smallmouth bass on juvenile salmon vary from 0 to 3.89 salmon consumed per smallmouth bass each day across locations in PNW. A bioenergetics model of smallmouth bass consumption suggests the interaction of water temperature and timing of salmonid outmigration influences the magnitude of smallmouth predation. Lessons explored for smallmouth bass can be applied to other non-native sport fish in the PNW.

\section{Studies on Largemouth Bass (Micropterus salmoides) Designated as Top Nuisance Fish in Republic of Korea}

\author{
Jinwon Seo \\ University of Idaho \\ Presenter: Jinwon Seo, (208)995-3828, jinwonseo91@hanmail.net
}

Since 1929, there have been many kinds of fishes, which are called as invasive/introduced species, in order to use them as pet, aquaculture, resource production, and experiments. Among them, largemouth bass (LMB, Micropterus salmoides) was imported from America with similar species, smallmouth bass (SMB, Micropterus dolomieui) in 1973. Thereafter, they were released into natural environment by mistake, and LMB has spread their habitats abroad in most Korean watersheds. Because LMB play the role of top consumer in streams, rivers, and reservoirs, many researchers concern on disturbance of aquatic ecosystem. Ultimately, the ministry of Environment designated largemouth bass with bluegill (Lepomis macrochirus) as an ecological disturbing fish in February 1998, and the government has been trying many efforts with specialists in order to remove them or to reduce at least their habitats and populations from natural waterbody. Therefore, it is very important to investigate basic studies such as their growth, feeding, reproduction, and general biology in our watershed even though there are a lot of information and publications on them in America. Objectives of the monitoring study were to examine growth states (length frequency, growth rate, and condition factor) of LMB inhabiting Andong Reservoir, to measure a few biological parameters (gonadosomatic index and hepatosomatic index) by sex, to determine a fecundity (by egg counting), and to compare their nutritional 
condition with $L M B$ in different areas. The findings would provide fundamental information about $L M B$ and will be used for regulation of LMB in streams and reservoirs in Republic of Korea.

\title{
Long-Term Changes in Nebraska's Stream Fish Assemblages
}

\author{
Christopher D. Smith ${ }^{1}$, Jesse Fischer ${ }^{2}$, Michael Quist ${ }^{3}$ \\ ${ }^{1}$ Idaho Cooperative Fish and Wildlife Research Unit, University of Idaho \\ ${ }^{2}$ lowa State University Department of Natural Resources Ecology and Management \\ ${ }^{3}$ U.S. Geological Survey, Idaho Cooperative Fish and Wildlife Research Unit, University of Idaho \\ Presenter: Christopher D. Smith, (712)261-0203, smit8051@vandals.uidaho.edu
}

Nebraska has undergone numerous anthropogenic alterations and land use changes since European settlement. Correspondingly, fish assemblages in small streams have likely experienced changes in structure in response to these alterations. Changes in Nebraska's lotic fish assemblages were examined with a comparison of site-specific, presence-absence data from historic (1939-1940) and contemporary sampling (2003-2005; $N$ =183). Our research indicates that some species have increased (e.g., green sunfish Lepomis cyanellus, bluegill Lepomis macrochirus), while others have decreased (e.g., plains topminnow Fundulus sciadicus, orangespotted sunfish Lepomis humilis) in overall proportion of occurrences from historic to current times. Additionally, it appears piscivore richness, number of introduced species, and game species richness have increased from historic to current times. Nonmetric multidimensional scaling analysis indicated taxonomic and functional assemblage structure differed between historic and contemporary samples. Overall, Nebraska's lotic fish assemblage structure has not dramatically shifted over the last 65 years; however, a general increase in species richness has occurred and some sensitive species (e.g., flathead chub Platygobio gracilis, western silvery minnow Hybognathus argyritis, plains topminnow) have declined in occurrence from historic times.

\section{Origin of Hatchery Steelhead Kelts Determined by Parentage-Based Tagging (PBT)}

Craig A. Steele ${ }^{1}$, Michael W. Ackerman ${ }^{1}$, Maureen A. Hess ${ }^{2}$, Shawn R. Narum ${ }^{3}$ and Matthew R. Campbell ${ }^{4}$

${ }^{1}$ Pacific States Marine Fisheries Commission (PSMFC) / Idaho Department of Fish and Game (IDFG), Eagle Fish Genetics Lab

${ }^{2}$ Columbia River Inter-Tribal Fish Commission (CRITFC), Hagerman Genetics Lab 3Columbia River Inter-Tribal Fish Commission

${ }^{4}$ Idaho Department of Fish and Game, Eagle Fish Genetics Lab

Presenter: Craig A. Steele, (208)939-6713, craig.steele@idfg.idaho.gov

One promising alternative to mechanical tagging methodologies used for monitoring hatchery steelhead is the genetic approach of parentage-based tagging (PBT). PBT involves the annual genotyping of all broodstock at each hatchery of interest thereby creating a database of parental genotypes for each broodyear. Progeny from any of the genotyped hatchery parents can then be non-lethally sampled at any life stage and assigned back to their hatchery of origin, the exact broodyear they were produced, and even to their individual parents. The implementation of a PBT program for hatchery steelhead in the Snake River basin began in 2008 and has resulted in the unprecedented ability to mark millions of hatchery-origin fish. Because PBT tagged hatchery adults are now returning to the Snake River basin, we now have the ability to explore research questions that previously were difficult or impossible to investigate with traditional mechanical tags. In this study we use PBT to determine the origin of hatchery kelts. Thousands of kelts pass over Lower Granite Dam annually and it is estimated that up to $50 \%$ of these kelts can be of hatchery origin. The effect these hatchery fish have on wild populations by spawning outside the hatchery is largely unknown and an issue of concern. Determining the origin of hatchery kelts is a first step in improving our management of 
these fish. Genetic samples from 500 hatchery kelts were collected in 2011 as they out migrated over Lower Granite Dam. Assignment results of the kelts to their hatchery of origin will be presented.

\title{
Evaluation of the Effectiveness of Several Hook Types at Minimizing the Occurrence of Deep Hooking Stream Trout when Bait Fishing
}

\author{
Christopher L. Sullivan, Kevin A. Meyer and Daniel J. Schill \\ Idaho Department of Fish and Game \\ Presenter: Christopher L. Sullivan, (208)465-8404, chris.sullivan@idfg.idaho.gov
}

We compared deep hooking rates and capture efficiency for stream-dwelling trout caught with several common bait fishing hooks including three different circle hooks. In one study, anglers caught 583 trout using baited inline circle hooks, inline J hooks, and offset J hooks fished actively and passively and found the deep hooking rate $( \pm 95 \%$ confidence intervals) for inline circle hooks $(15 \pm 5 \%)$ was lower than offset J hooks $(19 \pm$ $5 \%)$ and inline J hooks ( $27 \pm 6 \%)$, but capture efficiency was also lowest for inline circle hooks. Deep hooking rate was influenced by hook type, fish length, angler, and fishing method (active or passive), but not by species. Deep hooking was always higher for passive fishing than actively fishing the same hook. In a second study, anglers landed 780 trout using baited inline and offset circle hooks and inline and offset J hooks. In this study, hook dimensions were nearly identical between the circle and J hooks. Deep hooking rates were similar for all hook types but was lowest for offset circle hooks $(25 \pm 6 \%)$, followed by inline circle hooks ( $27 \pm$ $7 \%)$, offset J hooks ( $27 \pm 6 \%$ ), and inline J hooks ( $29 \pm 6 \%)$. Again, deep hooking was always higher for passive fishing than for active fishing the same hook. Our results show that the size and type of circle hook may be an important factor for minimizing deep hooking, and some circle hooks may not be more effective than conventional J hooks at reducing deep hooking when bait fishing.

\section{Deep Water Spawning Observations and Effective Incubation Habitat Modeling for Redband Trout, Spokane River, WA}

Tim Vore

Avista Corporation

Presenter: Tim Vore, (509)495-8612, tim.vore@avistacorp.com

Redband trout spawning patches were inventoried and mapped along a 10 mile reach of the Spokane River. Spawning redds were surveyed during April. Water depth and velocity measurements at the redds were used to develop spawning habitat suitability criteria. Spawning and incubation habitat was mapped at each spawning patch over a wide range of discharges. The empirical data were used to develop continuous spawning and incubation habitat versus discharge relationships at each patch. The data from the individual patches were combined to create a model of effective spawning habitat for the river over a wide range of initial spawning and end of incubation discharges (1,000 to 25,000 cfs). Redband trout were primarily spawning in deep water (average depth 3.5 feet, maximum depth 5.3 feet). The Spokane River typically has a rapidly declining hydrograph in late May/early June prior to emergence. Deep water spawning protected redds from dewatering. Effective spawning habitat modeling was used to create a simple flow versus effective spawning habitat matrix tool to help manage flow and spawning habitat. 


\title{
Invasive Aquatic Plant Treatment and Prevention in Idaho
}

\author{
Thomas Woolf \\ Idaho State Department of Agriculture \\ Presenter: Thomas Woolf, (208)608-3404, twoolf@agri.idaho.gov
}

In 2006 expanding Eurasian watermilfoil (EWM) populations in Idaho prompted an aggressive treatment program state-wide. Treatments have been conducted in over 30 waterbodies in the state using a variety of herbicides as well as diver methods. Each treatment is surveyed to determine efficacy and significant reduction of EWM have been documented as well as increased native plant diversity. Now, with reduction in funding, large-scale treatments are no longer feasible and focus has turned to treating priority areas and prevention efforts. Other invasive aquatic plants are also becoming more established in the state and it is unclear what their impacts will be on the waters of Idaho.

\section{Resolving Cottid Confusion: Phylogeography of Sculpins in the Upper Columbia and Missouri River Basins}

\author{
Michael K. Young ${ }^{1}$, Kristy Pilgrim ${ }^{1}$, Kevin McKelvey ${ }^{1}$, Michael Schwartz ${ }^{1}$, Daniel Bingham ${ }^{1}$, and David A. \\ Schmetterling ${ }^{2}$ and Susan B. Adams ${ }^{3}$ \\ ${ }^{1}$ Rocky Mountain Research Station \\ ${ }^{2}$ Montana Fish, Wildlife and Parks \\ ${ }^{3}$ Southern Research Station, Oxford, Mississippi \\ Presenter: Michael K. Young, (406)542-3254, mkyoung@fs.fed.us
}

Sculpins (Family Cottidae) are small, benthic, and typically freshwater fishes indigenous to the Northern Hemisphere. They play critical trophic roles in streams, rivers, and lakes in North America, but their identification is problematic because of morphological similarity among putative species and within-species variability in diagnostic traits. Consequently, taxonomists and fisheries ecologists have failed to reach consensus on the identity and distribution of species that constitute the sculpin fauna of the upper Columbia and Missouri River basins. To resolve this issue, we sampled nearly 400 streams in these two basins to identify sculpin distributions, and used two portions of the mtDNA genome and nuclear microsatellites to assign individuals to particular species. We found that only one of the three species currently reported from the upper Columbia and Missouri River basins in Montana was actually present; the other two potential species represent undescribed taxa. A fourth potential species, primarily in the Spokane River basin in Idaho, is undescribed. Two of the undescribed taxa are distributed across major watershed divides, which either reflects paleohydrological connections or recent human-assisted translocation. Each of these groups exhibits introgressive hybridization with the third undescribed taxon where they co-occur. Collectively, the phylogenetic relations of these previously unrecognized groups are poorly resolved relative to other sculpins. We conclude that a wholesale revision of the taxonomy of sculpins in inland waters of the western U.S., coupled with broad-scale sampling to clarify species distributions, appears warranted. 


\title{
Poster Abstracts in Alphabetical Order
}

\section{Effects of Winter Ice Dynamics on Periphyton and Seston in a Central Idaho River Ecosystem.}

\author{
Ryan Blackadar, C.V. Baxter and J.M. Davis \\ Idaho State University \\ Presenter: Ryan Blackadar, (208)756-7773, blacrya2@isu.edu
}

Ice may influence organic matter dynamics in temperate rivers, but few studies have addressed these processes. Ice cover, which reduces light, and ice-out events, which scour the channel, may interact to control variation in quantity and quality of periphyton and seston. We monitored ice (via interval cameras) and conducted winter sampling in Big Creek, a $7^{\text {th }}$ order river located in the wilderness of central Idaho. Periphyton and seston were sampled monthly during winter 2010-2011 and chlorophyll-a concentration and ash free dry mass were determined. Onset of ice cover was associated with a $40 \%$ reduction in chlorophyll-a relative to AFDM, but this was principally manifested along river margins with laminar flow. Following a December ice-out event, scour greatly reduced periphyton AFDM though this effect varied by habitat. Moreover, due to a period of open water following scour, chlorophyll-a appeared to have increased rapidly. Seston dynamics mirrored those of periphyton except that apparently ice-out increased the entrainment of detritus from riverbanks. Because ice regimes may shift with changing climate, this may impact river organic matter and food web dynamics.

\section{The Snake River Sockeye Captive Broodstock Program: A Review of the First Twenty Years and What's Migrating Upstream in the Future}

\author{
Travis Brown ${ }^{1}$, Dan Baker ${ }^{1}$, Mike Peterson ${ }^{1}$, Jeff Heindel ${ }^{1}$, Chris Kozfkay ${ }^{1}$, Tom Flagg ${ }^{2}$, Des Maynard ${ }^{2}$, Carlin \\ McAuley $^{2}$, Debbie Frost ${ }^{2}$, Greg Baesler ${ }^{3}$ and Jeff Gislason ${ }^{3}$ \\ ${ }^{1}$ Idaho Fish and Game \\ ${ }^{2}$ NOAA Fisheries \\ ${ }^{3}$ Bonneville Power Association \\ Presenter: Travis Brown, (208)939-4114, travis.brown@idfg.idaho.gov
}

Snake River sockeye salmon Oncorhynchus nerka were listed as endangered in 1991. A captive broodstock program was initiated at this time to prevent species extinction and to protect the genetics of the population. To date, the Sockeye Program has been successful in conserving the genetics of the founding population. The Sockeye Program has also reared and released small numbers of eggs, juveniles, and adults back to the habitat each year as a result of spawning captive broodstocks maintained the Eagle Fish Hatchery in Idaho and NOAA Fisheries facilities in Washington. The results of these releases have returned small numbers of anadromous sockeye salmon to the Sawtooth Basin. As rearing space for full term sockeye smolt releases has been made available at other facilities, the Sockeye Program has been successful in returning larger numbers of anadromous sockeye to the Sawtooth Basin. The Sockeye Program has shown a small smolt rearing program (80,000 to 180,000 smolts reared) resulted in a high of 1,355 sockeye salmon returning to the Sawtooth Basin in 2010. The Eagle Fish Hatchery expanded the sockeye captive broodstock (from 300 to 600 adults) in 2007, as well as provided isolated holding space for anadromous sockeye salmon transferred to Eagle Fish Hatchery for incorporation into the captive broodstock. The NOAA Fisheries facility is currently being modified to increase the captive broodstock held at Burley Creek Fish Hatchery. The Sockeye Program has purchased a facility in Springfield, Idaho that will be reconstructed to provide rearing for up to 1,000,000 sockeye smolts annually. After implementation of the smolt release program is under way, anadromous adult sockeye returns should increase dramatically. The next steps would be to implement an integrated hatchery program and eventually working towards recovery goals of 1,000 natural spawners in Redfish Lake and 500 natural spawners in two additional lakes (Pettit and Alturas lakes). 


\title{
Analysis of Survival and Downstream Migration Characteristics of Steelhead Kelts Using Instream PIT-Tag Arrays in the Potlatch River Drainage, ID
}

\author{
Nicolas Davids ${ }^{1}$ and Brett Bowersox ${ }^{2}$ \\ ${ }^{1}$ Pacific States Marine Fisheries Commission \\ ${ }^{2}$ Idaho Department of Fish and Game \\ Presenter: Nicolas Davids, (208)799-5010, nick.davids@idfg.idaho.gov
}

Iteroparity has been documented within inland steelhead populations such as those found in the Snake River Basin; however, information on kelt survival and outmigration characteristics from spawning tributaries is still lacking. To address this issue, we examined PIT-tag interrogation data from instream PIT-tag arrays and dam passage facilities to estimate reach based survival and outmigration travel rates for steelhead from two different release sites within the drainage, Big Bear Creek (lower Potlatch River drainage) and Upper Potlatch River. Overall kelt survival from release sites to the mainstem Potlatch River instream array and Lower Granite Dam was 51.6\% and 8.6\% respectively. Kelts from Big Bear Creek release sites survived to the tributary array, mainstem Potlatch River instream array and Lower Granite Dam at 70.3\%, 62.4\% and 9.4\% respectively. Survival from Upper Potlatch River release sites to tributary array and mainstem Potlatch River instream array are $\mathbf{7 2 . 7 \%}$ and $18.2 \%$ respectively. Mean kelt travel rates from Big Bear Creek to the mainstem Potlatch River instream array, and subsequently from the mainstem Potlatch River instream array to Lower Granite Dam was $24.3 \mathrm{~km} /$ day and $10.2 \mathrm{~km} /$ day respectively. Average kelt travel rate from the Upper Potlatch River to the mainstem Potlatch River instream array was $20.2 \mathrm{~km} /$ day. Survival and travel rate from the mainstem Potlatch River instream array to Lower Granite Dam could not be estimated due to low sample size. A large portion of kelts $(\leq 30 \%)$ in this study were not detected at downstream arrays, suggesting that these fish did not survive short distances $(<3.5 \mathrm{rkm})$ to the tributary array. Additional evaluations of kelt detection efficiency at Snake and Columbia River dams and kelt outmigration mortality are needed; however, results from this study provide baseline data for evaluating kelt mortality and life history characteristics associated with iteroparity among inland steelhead populations.

\section{Suitability of Habitat and Water Quality in the Meadow Reach of Boulder Creek for Rainbow Trout}

\author{
Donnelly Elementary School $5^{\text {th }}$ graders and Deirdre Bingaman \\ Donnelly Elementary School $5^{\text {th }}$ Grade Teacher and the McCall Outdoor Science School \\ Presenter: Deirdre Bingaman, (208)325-4433, bingamand@mdsd.org
}

Donnelly Elementary School $5^{\text {th }}$ graders raise rainbow trout in their classroom through the Trout in the Classroom Project and release these trout into Boulder Creek by the school. The students investigated whether the water quality and habitat in Boulder Creek was suitable for rainbow trout this fall with the McCall Outdoor Science School by comparing an upstream less disturbed site in the meadow reach to the more disturbed site downstream by their school. Students monitored temperature, $\mathrm{pH}$, dissolved oxygen, conductivity, phosphates, flow rate, and nitrates at both sites, assessed macroinvertebrate populations, snorkeled to assess fish populations and made observations about habitat in Boulder Creek. The students also compared their Trout in the Classroom aquarium water quality to the Boulder Creek water quality.

The results show that the upstream site provides better overall habitat for trout while the downstream site by the school provided adequate habitat but had high nitrate levels. 


\title{
Marine Mammal Predation in the Lower Columbia River
}

\author{
Douglas Hatch and John M. Whiteaker \\ Columbia River Inter-Tribal Fish Commission \\ Presenter: Douglas Hatch, (503)731-1263, hatd@critfc.org
}

The intent and focus of this project is to address marine mammal predation on Columbia River salmonids. This is a new and growing impact to salmonids particularly in the last several years (Pinniped Task Force 2007). To date, most of the attention has focused on the area just below Bonneville Dam, where salmon are concentrated before they enter the fish ladders and where visual estimates of predation rates are easier to develop (Stansell et al. 2011). Over the last two years (2010-11) sea lions killed over 10,000 salmonids within a viewable distance of Bonneville Dam. However, there are anecdotal reports of extensive sea lion predation in areas below the dam that are not visible from the dam. This unaccounted for predation may be greater than the observed predation. This project addresses objectives required under the Hydro System Biological Opinion Reasonable and Prudent Actions (RPA 49 and 69). These objectives are:

Objective 1. Conduct boat-based non-lethal sea lion hazing in the Bonneville Dam tailrace annually generally between March 1 and May 31.

Objective 2. Develop a system to enumerate sea lions and estimate predation throughout the lower Columbia River.

Objective 3. Track movements of individual sea lions at various spatial scales in the Columbia River using acoustic telemetry.

\author{
Evaluating Tiger Muskellunge to Remove Brook Trout from Idaho Alpine Lakes \\ Eric A. Herrera and Martin Koenig \\ Idaho Department of Fish and Game, Nampa Research Office \\ Presenter: Eric A. Herrera, (208)465-8404, eric.herrera@idfg.idaho.gov
}

Nonnative brook trout Salvelinus fontinalis populations in alpine lakes threaten the persistence of native cutthroat trout Oncorhynchus clarki and bull trout Salvelinus confluentus in downstream Idaho streams. Using predatory fish to manage brook trout populations is an attractive alternative to other techniques such as gillnetting, electrofishing, or chemical treatments, particularly in remote wilderness settings. Stocking tiger muskellunge Esox luscious $x$ E. masquinongy may be an efficient means for eliminating some brook trout populations. Study lakes were initially surveyed in 2005 or 2006 to characterize the resident brook trout populations. In 2007, nine alpine lakes containing brook trout populations were planted with tiger muskellunge at 40 fish/ha density. Lakes were surveyed from 2008 through 2011 to compare changes in brook trout size and relative abundance before and after stocking tiger muskellunge. Relative abundance of brook trout declined substantially in most lakes, while average length and weight increased following stocking. Mean catch rates of brook trout declined from 22.8 per net-night before planting tiger muskellunge, to 2.6 per net-night in 2011. Prior to tiger muskellunge, mean brook trout length was $212 \pm 3 \mathrm{~mm}(n=519)$. After stocking, mean brook trout length was $246 \pm 6 \mathrm{~mm}(n=132)$ in 2008, $264 \pm 7 \mathrm{~mm}(n=138)$ in 2009, 237 $\pm 7 \mathrm{~mm}(n=84)$ in 2010 , and $256 \pm 10 \mathrm{~mm}(n=76)$ in 2011, indicating a consistent increase in mean size. Catch rates of brook trout declined slightly in control lakes, while size remained unchanged. Brook trout may overcome eradication efforts by recolonizing lakes from refuge habitats or through density-dependent recruitment success. However, this study shows tiger muskellunge can improve the size structure of brook trout populations. While it appears tiger muskellunge may be successful in eliminating brook trout in some lakes, we recommend combining introductions with other control methods to increase the chances of success. 


\title{
Genetic Estimation of Stock Abundance and Run-timing of Interior Columbia River Steelhead Passing Bonneville Dam
}

\author{
Jon E. Hess, Shawn Narum and John Whiteaker \\ Columbia River Inter-Tribal Fish Commission, Hagerman Genetics Lab \\ Presenter: Jon E. Hess, (208)837-9096 ext. 1107, hesj@critfc.org
}

The Columbia River Basin supports ESA listed stocks of wild steelhead as well as hatchery supplemented populations. Accurate estimates of stock proportions that account for both hatchery and wild fish throughout the migration season are useful information for steelhead fisheries managers. In this study, we determined how finely and accurately genetic stock identification (GSI) analysis could distinguish among stocks of steelhead within the Columbia River Basin. Further, we characterized each stock's run-timing distribution, and estimated abundance. Tissue samples were obtained from adult steelhead during migration runs at Bonneville Dam in each of three years between 2009 to 2011 ( $n=2468,1760$, and 1394 respectively). Samples were pooled into 13 biweekly strata (mean $n=144$, range 4 - 466 per strata) spanning the majority of the run-year from April to October. Genotypes from 192 single nucleotide polymorphism (SNP) loci were obtained from steelhead mixtures and a genetic baseline was used to perform GSI. This DNA marker-type represents the most recent technological advance in genetic tools applied to steelhead stocks at Bonneville Dam, and we include discussion of the benefits of this marker-type. Variation in stock proportions was minimal when comparing similar time strata across years, while intra-annual variation across time strata within the migrating season was relatively large. This study demonstrates great potential for the application of GSI in the management of Columbia River steelhead fisheries evidenced by high accuracy of stock assignment, and the ability to discriminate steelhead stocks by run-timing and estimate hatchery and wild components of stock abundance.

\section{Prevalence of Otolith Aberrancy in Hatchery-Reared Juvenile Steelhead Trout from the Snake River Basin}

\author{
Heath Hewett ${ }^{1}$, Christine Moffitt ${ }^{2}$ and Zachary L. Penney ${ }^{1}$ \\ ${ }^{1}$ University of Idaho \\ ${ }^{2}$ US Geologic Survey, Idaho Cooperative Fish and Wildlife Research Unit \\ Presenter: Heath Hewett, (208)790-1827, hewe4693@vandals.uidaho.edu
}

Otoliths or earstones are located in the inner ears of teleost fish and commonly used for age and growth analysis. Otoliths are acellular, metabolically inert, and not subject to resorption during prolonged periods of fasting or stress, making them more chronologically accurate than other calcified structures such as scales. However, aberrancies (abnormalities) in the otolith growth sequence thought to be caused by variations in crystallization during accretion can obscure portions of the otolith for accurate age and growth estimates. Little is known about the factors that influence otolith aberrancy, but past work in anadromous salmonids has shown the otolith aberrancy appears to be more common in hatchery-reared fish than those existing in the wild. A greater frequency of aberrancy in hatchery-reared salmon otoliths suggests that environmental conditions may influence otolith aberrancy, especially during early rearing. In 2010 and 2011, sagittal otoliths were collected from juvenile hatchery-reared steelhead trout at Hagerman National Fish Hatchery (HNFH) and Dworshak National Fish Hatchery (DNFH) to examine the occurrence of otolith aberrancy. We found that $51 \%$ of DNFH and $5 \%$ of HNFH otoliths had aberrant growth on the left, right, or both earstones. The observation that aberrancy could occur in a single otolith from the sagittal pair suggests that physiology and genetics may also be influential to otolith accretion in addition to external environmental conditions. The prevalence of aberrancy in DNFH steelhead compared to HNFH is unclear; however, differences in hatchery water source and temperature may be important. Some otoliths in adult steelhead from DNFH show aberrancy, suggesting that aberrancy does not hinder fish survival. 


\title{
Assimilation Efficiency of Utah Sucker and Speckled Dace Feeding on Chironomidae Larvae at Different Temperatures
}

\author{
Nichelle Heyrend, K. C. Donner and C. V. Baxter \\ Stream Ecology Center, Department of Biological Sciences, Idaho State University, Pocatello, ID \\ Presenter: Nichelle Heyrend, (208)201-4062, heyrnich@isu.edu
}

Assimilation efficiency is an important, yet often overlooked component of many studies in fish trophic ecology. A common assumption in these studies is that assimilation efficiencies are constant despite growing evidence to the contrary. Some studies have addressed variability in assimilation efficiency with respect to temperature however; our understanding of consumer-specific variation in assimilation efficiency is limited. We examined assimilation efficiency of speckled dace and juvenile Utah sucker feeding on Chironomidae at $20 \pm 3 \mathrm{C}$ and $12 \pm 3 \mathrm{C}$. We chose these as species representative of fish families (Cyprinidae and Catostomidae) that are ecological important in rivers of the western U.S. but whose assimilation efficiencies are poorly understood, and investigated their utilization of Chironomidae larvae because they are among the invertebrate prey most commonly consumed by these fishes. Individuals of each species were held in 7.5 gallon aquaria and fed a diet of frozen Chironomidae larvae. Feces were collected throughout the experiment assimilation efficiency was determined by using an indigenous marker technique. Assimilation efficiency was highest in the $20 \mathrm{C}$ treatment containing Utah sucker and lowest in the $12 \mathrm{C}$ treatment containing dace. For each species, assimilation efficiency was higher in the $20 \mathrm{C}$ treatment than the $12 \mathrm{C}$ treatment. Higher assimilation efficiencies in Utah sucker may be attributed to longer gut lengths relative to speckled dace. Variability in assimilation efficiency associated with temperature can be important to account for in bioenergetic models. Efficiencies estimated through this study may be useful in parameterizing bioenergetic models for these and related fishes.

\section{Genetic Analysis of Redband Trout in the Malad River, ID}

\author{
Tabitha Holden (student) ${ }^{1}$,Clint Kennedy (teacher), Tracy Richter ${ }^{2}$ and Matthew Campbell ${ }^{3}$ \\ ${ }^{1}$ Cascade Jr. Sr. High School, Cascade, Idaho \\ ${ }^{2}$ Idaho Power Company, Environmental Affairs Department \\ ${ }^{3}$ Idaho Department of Fish and Game \\ Presenter: Tabitha Holden, tabitha holden@yahoo.com
}

There are two hydroelectric dams on the Malad River in southwest Idaho owned and operated by the Idaho Power Company (IPC). Idaho Power completed fish passage facilities on the lower dam in January of 2008, and since that time over 2,500 redband trout have been observed passing through the facility. As part of the Malad Fish Passage Plan, the IPC has objectives to monitor the genetic diversity and differentiation of redband trout in the mainstem Malad River (upper, middle, and lower reaches), Cove Creek (a tributary to the Malad River), and the mainstem Snake River. To address these objectives I worked with IPC biologists to collect non-lethal tissue samples from redband trout from each of these sites in the fall of 2011. I then learned genetic protocols and procedures in the Idaho Department of Fish and Game's genetics lab and genetically analyzed the samples using single nucleotide polymorphism genetic markers. I then tested genetic diversity and differentiation among sites and compared those results to a previous study conducted in 2002. The results from this study were generally very similar to the previous study with low genetic differentiation observed among redband trout collected from the Upper and Middle Malad sites, and high genetic differentiation between Cove Creek and all other sampling reaches. However, results from my study suggest that the redband trout population in the Lower Malad River has changed and is now less similar to the population above the lower dam and more similar to redband trout in the Snake River. Although there has 
been a substantial amount of redband trout moving past the dam, it is probably too soon to see the effects genetically. However, fish passage and reproduction may decrease differences among sites and help maintain genetic diversity over time. This project will contribute to long-term monitoring efforts.

\title{
A Large-Scale Field Assessment Using Underwater Epoxy to Permanently Install Sensors for Full Year Temperature Monitoring in Mountain Streams
}

\author{
Dona L. Horan, Sherry Wollrab, Daniel J. Isaak and Brett B. Roper ${ }^{1}$ \\ U.S. Forest Service, Rocky Mountain Research Station, Boise Aquatic Sciences Laboratory \\ ${ }^{1}$ U.S. Forest Service, Fish and Aquatic Ecology Unit, Utah State University \\ Presenter: Dona L. Horan, dhoran@fs.fed.us
}

Stream temperature regimes are fundamentally important to understanding pattern and process in aquatic communities. Modern digital sensors can provide accurate and repeated temperature measurements that span multiple years, but are rarely deployed for more than a few summer months in mountain streams due to logistical constraints with seasonal stream access and concerns that large annual floods will destroy sensors. We developed a rapidly applied protocol (sensor installation takes $\sim 20$ minutes) that uses underwater epoxy to attach sensors to large rocks that makes full year stream temperature monitoring feasible and cost effective. Initial field trials during the winter of 2009/2010 suggested temperature measurements were not biased by attachment to rocks and $82 \%$ of epoxied sensors ( 9 of 11) were retained through spring floods. A larger scale field assessment was initiated during the summer of 2010 wherein 300 temperature sensors were deployed in streams ranging in channel slope from $0.1 \%-16 \%$ across the northwest U.S. Eighty-six of these sites were checked for sensor retention after the large spring flood in 2011 and $74 \%$ (64 of 86 ) of sensors remained in place recording stream temperatures. Retention success was inversely related to channel slope and averaged $85 \%$ where slopes were $<3 \%$ that are typical of most fishbearing streams. Our results indicate that the underwater epoxy technique is viable for installing temperature sensors in a wide range of mountain streams where large substrates and suitable attachment sites are common. Moreover, the technique reduces the cost of temperature monitoring by reducing the number of site visits to $\leq 1$ /year rather than the current norm of 2 /year for summer data and 5 years of temperature measurements may be obtained for $\$ 130$ in equipment costs (primarily the cost of the sensor) given current memory and battery capacities of temperature sensors. More than 400 additional stream sites were instrumented with temperature sensors using underwater epoxy during the summer and fall of 2011 to continue expanding the regional temperature monitoring network. Data from this network will contribute in future years to improved understanding of stream thermal regimes, alterations associated with climate change, and the thermal ecology of aquatic organisms.

\section{A Large-Scale Nutrient Addition Experiment in the Kootenai River, Idaho: Effects of Phosphorous on Water Chemistry, Algal Production, and Periphyton Taxonomy Genny Hoyle ${ }^{1}$, Charlie Holderman ${ }^{1}$, Paul Anders ${ }^{2}$, Bahman Shafii ${ }^{3}$ and Ken Ashley ${ }^{4}$ \\ ${ }^{1}$ Kootenai Tribe of Idaho \\ ${ }^{2}$ Cramer Fish Sciences \\ ${ }^{3}$ University of Idaho \\ ${ }^{4}$ British Columbia Institute of Technology \\ Presenter: Genny Hoyle, (208)267-3620, genhoyle@kootenai.org}

The Kootenai River in Idaho, Montana, and British Columbia has undergone cultural oligotrophication during the past century following diking, channelization, wetland drainage, and upstream impoundment. Using a replicated, in-river mesocosm experiment to assess small-scale response to nutrient addition, a multi-year whole-ecosystem nutrient enrichment experiment was performed to assess nutrient addition as an 
ecosystem restoration technique. The river was dosed with agricultural-grade ammonium polyphosphate (1034-0) from June through September, 2006 through 2010, to achieve an in-river TDP concentration of $3.0 \mu \mathrm{g} \cdot \mathrm{L}^{-}$ ${ }^{1}$. A fine-scale monitoring program included 8 sites (two upstream reference sites, one injection site, and 5 downstream treatment sites). The additions increased nutrient concentration and primary production. Atomic N:P ratios were significantly lower at treatment sites than reference sites. Total chlorophyll accrual rates were significantly higher at treatment sites than at reference sites. Mean algal biomass and algal cell density were significantly higher at treatment versus reference sites. Downstream from nutrient addition, diatom density increased and blue-green algae density decreased. Results confirmed nutrient addition as a useful ecosystem restoration technique for the Kootenai River.

Use of Hydrated Lime to Reducing the Risks of Release of Invasive Species From Boats and Ballast Systems Laura Hughes ${ }^{1}$, Amber Barenberg ${ }^{1}$, Tasha Britton ${ }^{1}$, Charles Withers-Haley ${ }^{1}$, Christine M. Moffitt ${ }^{2}$ and Barnaby

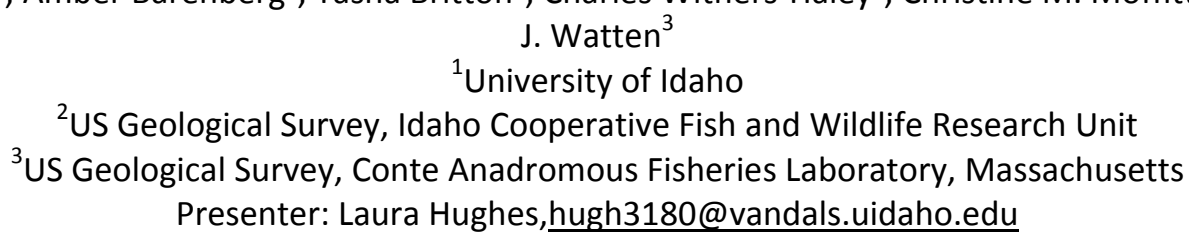

Global commerce has increased the risks of transporting of live organisms from one region to another. Large cargo ships use ballast tanks that are filled at ports to maintain their stability and structural integrity when there is no cargo on board. Moreover, simple cooling systems of smaller craft can contain sediments that could harbor and release alien species. We are working to provide an inexpensive and safe disinfection system using hydrated lime (calcium hydroxide) that can be used for large and small vessels alike to reduce risks of introducing invasive invertebrate species. Our laboratory test are concentrating on selected invasive mollusk species, as they are known to be among the most resistant to standard disinfection procedures, and many invasive mollusks have altered trophic systems in the receiving aquatic systems. Our first tests are with New Zealand mudsnails. We are determining the length of exposure needed for complete mortality at three different $\mathrm{pH}$ concentrations. Our tests are conducted in fresh and in brackish sea water (15 ppt) and two water temperatures. Once laboratory tests are completed with New Zealand mudsnails we plan to test with other invasive mollusks including quagga mussels.

\section{Quantifying the Rates of Hook Breakdown in Acidic Solutions \\ Tony Lamansky, Matthew Belnap and Erin Larson \\ Idaho Fish and Game}

Presenter: Tony Lamansky, Idaho Fish and Game, (208)465-8404, tony.lamansky@idfg.idaho.gov

Impacts of catch and release fishing on fish mortality and growth have been widely researched, but little information exists on the rate at which discarded hooks and gear break down in fish digestive systems. Our goal was to determine the rate of hook breakdown in fish digestive systems, as ingested gear may have detrimental impacts on fish health. We conducted a lab experiment simulating fish stomach conditions to measure the percent weight loss over time of hooks with different finishes and abrasion treatments. In our study, we evaluated hooks with five different finishes (silver nickel, black nickel, red lacquer, bronze and circle sea) and used three different treatments (untouched, scratched, bent barb) on each hook type. Hooks were immersed in a $\mathrm{pH} 2.0 \mathrm{HCl}$ solution and weighed weekly to calculate total percent weight lost over 6 months. The hook finish was responsible for the greatest effect on percent weight loss, while hook treatment had little effect. Bronze hooks had the highest percent weight loss at $15.6 \pm 0.6 \%$, while black nickel, silver nickel, and circle sea finished hooks did not have significantly different percent weight losses. Red lacquer finished hooks had the lowest percent weight loss at $1.4 \pm 0.5 \%$. Based on these results, hooks do not 
deteriorate quickly in stomach conditions, and certain hook finishes can slow the breakdown process. Since this study occurred in a laboratory setting, future research should include implanting hooks in a captive fish population to determine physiological impacts on fish and to calculate a more accurate rate of hook breakdown in fish digestive systems.

\title{
Evaluating the accuracy of sibling reconstruction programs using steelhead SNPs
}

\author{
Jesse McCane, Craig A. Steele, Christine Kozfkay and Matthew Campbell \\ Pacific States Marine Fisheries Commission (PSMFC) / Idaho Department of Fish and Game (IDFG), Eagle Fish \\ Genetics Lab \\ Presenter: Jesse McCane, (208)939-6713, jesse.mccane@idfg.idaho.gov
}

The ability to determine genealogical relationships among individuals within a sample of fish without parental information has many important conservation and management applications. Although several methods are currently available to estimate these relationships, they are computationally intensive and require highly informative genetic markers that are free of genotyping errors and mutations in order to provide accurate reconstruction. In this study, we used a powerful new set of 188 single nucleotide polymorphic markers (SNPs) developed for steelhead to compare the effectiveness of existing sibling reconstruction computer programs in correctly reconstructing family relationships using SNP genotypes from hatchery offspring with known parentage. The verification of the accuracy and performance of these methods could provide opportunities for assessing patterns of dispersal and estimating effective population size in future research programs where field collections often only target one or two cohorts and may not include parents.

\section{Determining the Maternal Origin of Juvenile O. mykiss in the Lapwai Basin, Idaho}

\author{
Alifia Merchant ${ }^{1}$, Emily Benson ${ }^{2}$, Jens Hegg $^{2}$ and Brian Kennedy ${ }^{2}$ \\ ${ }^{1}$ University of Ohio School of Environment and Natural Resources \\ ${ }^{2}$ University of Idaho \\ Presenter: Alifia Merchant, (708)724-4207, merchant.52@buckeyemail.osu.edu
}

Understanding the migratory behaviors of salmon is a critical step in their conservation. The Lapwai Basin, Idaho, is home to a threatened population of steelhead (Oncorhynchus mykiss) for which determining the relative contribution of anadromous and resident fish to the population is an important consideration in water utilization plans and management practices. The isotopic chemistry of ocean water is different than that of freshwater systems. Therefore, salmon that have spent a substantial amount of time in the ocean bear unique chemical signatures to the freshwater areas where they spawn, and females pass these signatures on to their progeny. The objectives of our study were to determine the maternal origin of a selection of juvenile steelhead from the Lapwai basin using stable isotope analysis, and to determine the feasibility of a non-lethal sampling method. Strontium isotope values obtained from otoliths give an accurate picture of the steelhead life history, but extracting otoliths is lethal. Sampling fin tissue to obtain nitrogen and carbon stable isotope values may be a non-lethal method to determine maternal origin. Twenty-two juvenile fish collected at five sites within the Lapwai basin between 2008 and 2010 were included in this study; their otoliths, fin tissue, and muscle tissue were extracted and analyzed for strontium isotope values (otoliths) or nitrogen and carbon stable isotope values (fin and muscle tissue). We also collected macroinvertebrates at each site and included these potential prey items in our nitrogen and carbon stable isotope analysis. We found a marine maternal signature in the otolith of each of the 22 fish analyzed. The nitrogen and carbon stable isotope values of the fin and muscle tissue, though closely correlated to one another, do not indicate a marine maternal origin, suggesting that the maternal signature may have been attenuated in these tissues. 


\title{
Status of Kootenai River White Sturgeon Population
}

\author{
Pete Rust \\ Idaho Department of Fish and Game \\ Presenter: Pete Rust, (208)769-1414, Pete.Rust@Idfg.Idaho.gov
}

The Kootenai River white sturgeon Acipenser transmontanus once provided an important fishery for Native Americans and residents of north Idaho. Since construction of Libby Dam in 1974, recruitment to age 1 has essentially failed, and subsequently this population was listed as endangered in September 1994. Recent modeling suggests the adult population is near 1,000 individuals and recruitment of wild juveniles is less than 10 individuals per year. Survival of hatchery reared juveniles exceeds $90 \%$ two years post release. IDFG's monitoring and evaluation program has determined that temperature, discharge, and the physicochemical variables resulting from the operation of Libby dam are either not consistently providing the correct cues for upstream migration into presumed natal spawning habitats or conditions in the present day spawning reach are no longer suitable for sturgeon egg survival. Until recently, it was thought that juvenile sturgeon rarely reside for long periods above Bonners Ferry. However, telemetry studies followed by recent sampling efforts by Montana Fish Wildlife and Parks in the canyon reach suggest that significant numbers of hatchery juvenile sturgeon are moving from Idaho into Montana. Moreover, many of the juvenile sturgeon captured here exhibit growth rates which greatly exceed those of the same year-classes captured in Idaho's meander reach. Other recent findings from egg deposition studies suggests that eggs may survive longer when deposited on gravel versus silt and clay substrates. Our research focus has shifted toward understanding spawning substrates and larval rearing habitats, which largely occur near and upstream of Bonners Ferry. This information may help guide future recovery efforts and bring us one step closer to understanding the combination of habitat conditions necessary for sturgeon recovery.

\section{Phenotypic and Genetic Identification of Bull Trout X Brook Trout Hybrids in the South Fork of the Salmon} River

\author{
Shiloh Ryker (student) ${ }^{1}$, Clint Kennedy (teacher) ${ }^{1}$, Laurie Janssen ${ }^{2}$, David Rhinehart ${ }^{2}$ and Matthew Campbell ${ }^{2}$ \\ ${ }^{1}$ Cascade Jr. Sr. High School, Cascade, Idaho \\ ${ }^{2}$ Idaho Department of Fish and Game \\ Presenter: Shiloh Ryker, shilohbeth1994@hotmail.com
}

Bull trout are listed as a threatened species under the Endangered Species Act. One of the main factors cited as threatening the species is hybridization with non-native brook trout. The purpose of my project was to test the use of a phenotypic key to differentiate bull trout, brook trout, and their hybrids and report hybridization levels in the South Fork of the Salmon River (SFSR), ID. The phenotypic key was previously developed by the Forest Service to differentiate adult fish from a drainage outside the Salmon River. To further test its effectiveness, I collaborated with Idaho Department of Fish and Game (IDFG) fishery technicians to capture bull trout, brook trout, and hybrids in the SFSR using a juvenile rotary screw trap. Captured fish were phenotypically identified, measured for length, and non-lethally sampled for fin tissue. I then extracted DNA from the tissue samples at the IDFG's genetics lab and tested the samples with diagnostic genetic markers run on agarose gels in our High School's genetics lab, as well as on the IDFG's 3100 genetic analyzer. I report the level of hybridization in the samples collected and the accuracy of the phenotypic key. 


\title{
Environmental Factors Affecting Aquatic Invertebrate Production in Wilderness Streams of Central Idaho
}

\author{
Matthew V. Schenk and Dr. Colden V. Baxter \\ Idaho State University \\ Presenter: Matthew V. Schenk, (208)282-2139, schenkermeister@yahoo.com
}

Invertebrate production is a useful metric which incorporates aspects of population dynamics as well as elements of abiotic environmental conditions. Shifts in production rates may have far reaching consequences for stream organism assemblages at multiple trophic levels. Rates of primary and secondary production are modulated by a variety of environmental pressures including changes in temperature and light availability. During 2010, six tributaries of Big Creek were monitored in attempts to elucidate relationships between environmental factors and stream organisms. Invertebrates were sampled bi-weekly to quantify abundance and production for the three dominant families; Baetidae, Simuliidae and Chironomidae. Production for each taxa was calculated using a non-cohort estimation process that utilized previously developed length-mass regression relationships for each respective taxa. Single pass snorkeling surveys were conducted to estimate density of Cutthroat trout (Oncorhynchus clarkii spp.). Environmental factors were collected through a variety of methods including the use of in-situ pressure transducers, and temperature loggers.

Photosynthetically active radiation (PAR) was collected two years previous at the same sites. Results indicated strong relationships between PAR and values for invertebrate abundance (0.91), biomass (0.94), and production rates (.90) when analyzed using a stepwise regression model. Cutthroat density values loosely tracked invertebrate abundance (0.86), biomass (0.72), and production (0.86). Cutthroat densities were also tied to PAR values with an $r^{2}$ value of 0.71 and loosely related to two aspects of hydrology; the slope of the descending limb of the hydrograph (0.88) and maximum discharge (0.84). Shifts in PAR availability can be accentuated by the potential effects of climate change. Particularly, changes in vegetation patterns in riparian areas due to altered fire regimes predicted in the North West. Alteration of stream function and organismal assemblages may have far reaching consequences for landscapes in light of climate change.

\section{Genetic Stock Identification of Kelt Steelhead in the Yakima River Basin Across Multiple Years and Collection Times}

Jeff Stephenson, Shawn Narum, Doug Hatch, David Fast, Bill Bosch, Todd Newsome and Ryan Branstetter Columbia River Inter-Tribal Fish Commission Presenter: Jeff Stephenson, (208)837-9096 ext. 1121, stej@critfc.org

Kelt steelhead have the potential to assist in the recovery of anadromous $O$. mykiss populations throughout the Columbia River Basin, and kelt reconditioning efforts are ongoing in the Yakima River sub-basin. In this study we attempt to identify which populations in the Yakima River contribute the largest proportion of kelts in this system. Steelhead of the Yakima River sub-basin are comprised of at least five genetically distinct populations (Satus $\mathrm{Cr}$., Toppenish $\mathrm{Cr}$., Ahtanum $\mathrm{Cr}$., Naches R., Teanaway $\mathrm{Cr}$.). Using reference collections from each of these five populations as a baseline, we used Genetic Stock Identification methods to estimate population composition of both downstream migrating kelts and their upstream migrant counterparts. Both groups were found to have differential migration timing based on sampling year and time of year. Additional variation in kelt composition was seen using gender and final known status (mortalities, survivors, pit tag detections). Proximity of the tributaries to the collection facilities may partially explain these results, but a genetic component to iteroparity cannot be ruled out. 


\title{
Evaluation of a Feed Exposure Challenge for Flavobacterium psychrophilum
}

\author{
Kali A. Turner, Amy Long, Tyson R. Fehringer and Kenneth D. Cain \\ University of Idaho \\ Presenter: Kali A. Turner, (208)874-3951, turn8117@vandals.uidaho.edu
}

Studies have shown that probiotics can be administered to fish through coated feed and remain viable in the gastrointestinal (GI) tract. Based on this and evidence of the GI tract being a major portal of entry for pathogenic bacteria, we sought to develop a feed-based challenge model to mimic the natural route of infection for Flavobacterium psychrophilum, the causative agent of Bacterial Cold Water Disease (BCWD). In the current study, a virulent strain of $F$. psychrophilum was grown in either tryptone-yeast extract-salt media (TYES) or iron-limited TYES (ILM) to increase pathogenicity. Rainbow trout (Oncorhynchus mykiss) (3.3 g/f) were split into triplicate tanks and fed a commercial trout diet coated with sterile TYES, F. psychrophilum grown in TYES $\left(1.6 \times 10^{8} \mathrm{CFU} / \mathrm{g}\right.$ feed), or F. psychrophilum grown in ILM ( $3 \times 10^{4} \mathrm{CFU} / \mathrm{g}$ feed). Feed was administered for seven consecutive days and fish were monitored for an additional 28 days. Serum was collected at 35 days post-exposure to determine if there was a significant increase in antibody titers. Fish were randomly sampled at 1 and 35 days post-exposure in an attempt to re-isolate $F$. psychrophilum from kidney, liver, spleen and gut. Mortality was monitored throughout the experiment. There were five mortalities and the difference between treatments was not significant. F. psychrophilum was not re-isolated from samples taken on either sampling date but was re-isolated from two mortalities. Antibody titers are currently being determined. Preliminary results suggest that exposure to $F$. psychrophilum via feed was capable of causing limited infection but did not result in a disease outbreak or produce mortalities at a level required for successful challenge model development However, it is possible that feed exposure may be more successful in smaller fish possessing less developed immune capabilities.

\section{Sensitivity Analysis of Kokanee Egg-to-Fry Survival Estimates in Lake Pend Oreille, Idaho}

\author{
Steven L. Whitlock, Presenter ${ }^{1}$, Michael C. Quist ${ }^{2}$ and Andrew M. Dux ${ }^{3}$ \\ ${ }^{1}$ University of Idaho \\ ${ }^{2}$ USGS, Idaho Cooperative Fish and Wildlife Research Unit, University of Idaho \\ ${ }^{3}$ Idaho Department of Fish and Game \\ Presenter: Steven L. Whitlock, (707)241-5296, whit4614@vandals.uidaho.edu
}

In the 1950s Lake Pend Oreille (LPO) produced an average annual kokanee Oncorhynchus nerka harvest of over a million fish, meanwhile providing a trophy rainbow trout $O$. mykiss fishery. Kokanee, which function as both a prey and sport species, declined precipitously in density beginning in the late 1960s following several biological and hydrological alterations to the system. The most significant alteration is believed to be the initiation of deep winter water level drawdowns associated with power production at Albeni Falls Dam. A sizeable portion of the kokanee population spawns over-winter on the lakeshore in LPO. Drawdowns are believed to decrease recruitment by reducing the availability of suitable spawning gravels, which primarily exist above the minimum winter lake elevation. Since 1996, the Idaho Department of Fish and Game has tested lake level manipulation strategy to determine if raising winter lake levels would increase kokanee recruitment. Kokanee recruitment response to raised lake levels is determined using a back-calculated estimate of egg-to-fry survival; this estimate is calculated using five other estimates and does account for the error of each estimate. To better understand the influence of sampling variability on our estimate of kokanee egg-to-fry survival, we used sensitivity analysis to assess sources of variability among the various subestimates. Several components we assessed included: hydroacoustic population estimates, proportional sexual maturity and hatchery-wild origin estimates derived from trawling, and fecundity estimates from mature kokanee collected using a weir. This analysis allowed us to evaluate sample size considerations and potential spatial and temporal sampling biases. Recommendations in existing literature and recent and more 
rigorous sampling efforts in LPO were incorporated into our evaluation of the existing egg-to-fry estimate methodology.

\section{NOTES}




\section{Thanks to our Meeting Sponsors!}
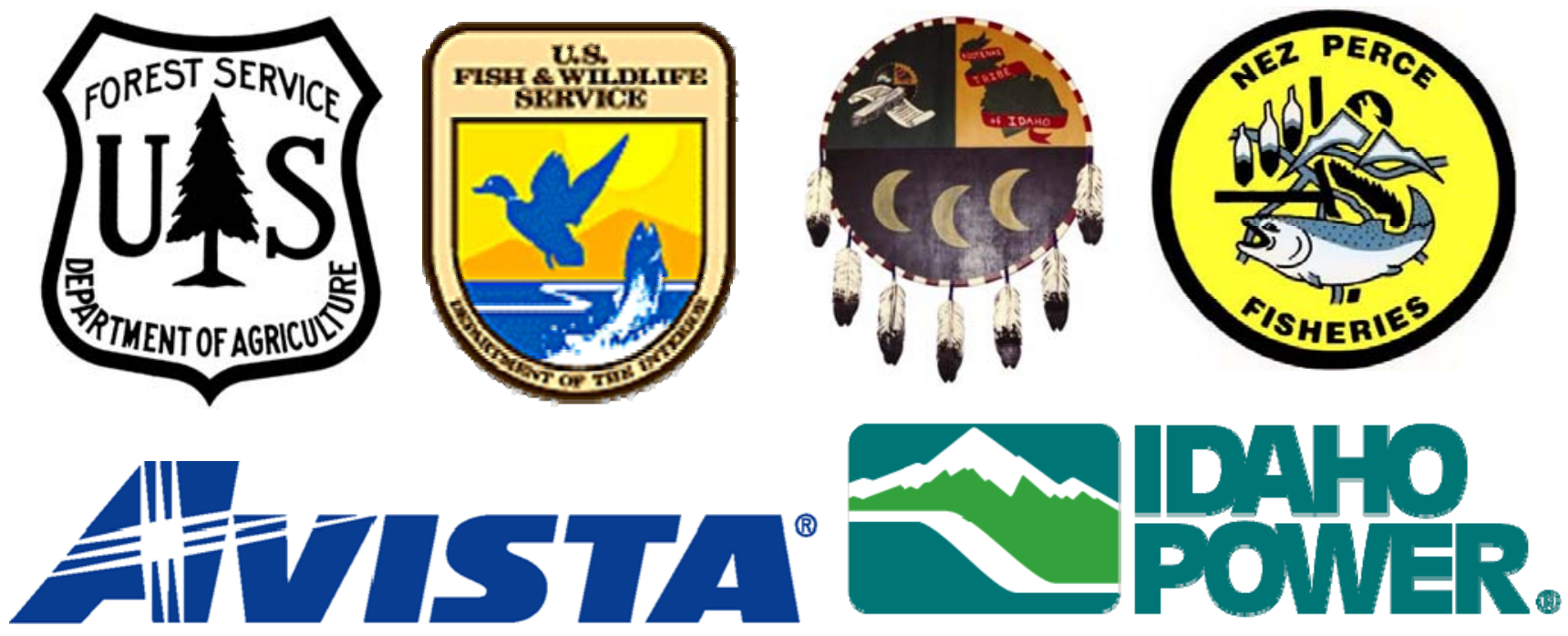

An IDACORP Company
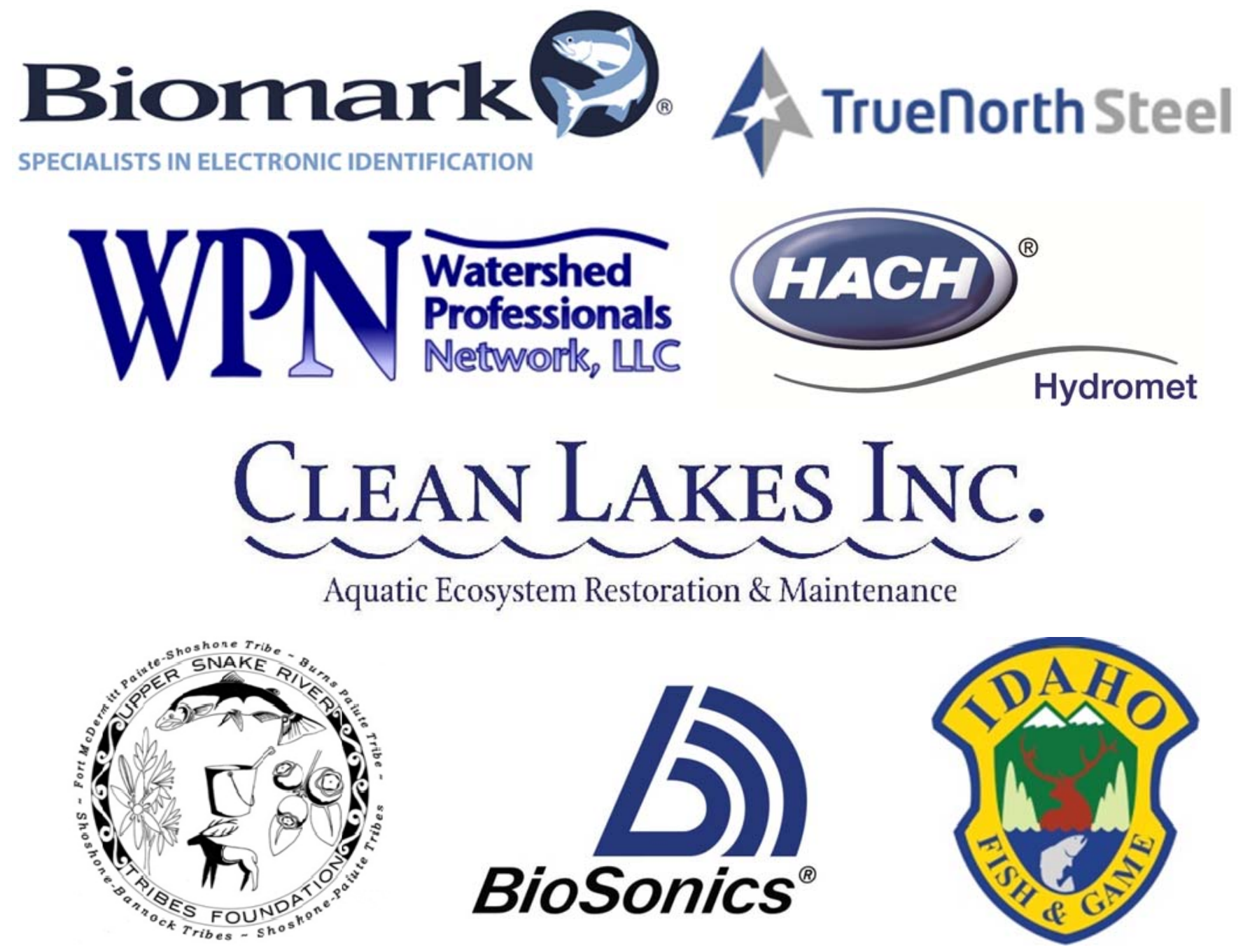